\title{
Graduação a distância: uma reflexão baseada no perfil dos acadêmicos do curso de Licenciatura em Biologia pelo Consórcio
}

\author{
Graduation distance course: a thought grounded \\ on the profile of the Bachelor's Degree in Biology students \\ at Northern Consortium, in Mato Grosso do Sul
}

lêda Maria Novaes Ilha ${ }^{1}$

iedailha@gmail.com

Danielle Serra de Lima²

moraes590@gmail.com

Sandra dos Santos Cereali ${ }^{3}$

scereali@gmail.com

Antonio Lino Rodrigues Sá ${ }^{4}$

antonio.lino@ufms.br

\section{Resumo}

A Educação a Distância surgiu na antiguidade, ganhou forma com a escrita impressa e novo significado com o advento da Internet. Em 2006, a UFMS e outras seis universidades constituíram o Consórcio Setentrional para Licenciatura em Biologia, objetivando qualificar professores leigos e demanda social, em nove municípios de Mato Grosso do Sul. Este trabalho tem como objetivo traçar o perfil desses acadêmicos. De 154 entrevistados, $71,1 \%$ são mulheres, e 29,9\% homens, a maioria com idade acima de 29 anos, concluíram o ensino médio há mais de 10 anos, casados, com filhos, trabalham e, no caso das mulheres, ainda cuidam do lar. Entre

\footnotetext{
1 Graduada em Ciências Biológicas Licenciatura pela Universidade Federal de Mato Grosso do Sul (UFMS); especialista em Morfofisiologia Básica pela UFMS; mestre em Ecologia e Conservação pela UFMS; mestre em Meio Ambiente e Desenvolvimento Regional pela Universidade para o Desenvolvimento do Estado e Região do Pantanal (Uniderp), especialista em Orientação Pedagógica em Educação a Distância pela UFMS; doutoranda em Ecologia e Conservação pela UFMS; professora assistente da UFMS.

${ }^{2}$ Graduada em Ciência Biológicas Licenciatura pela Universidade Federal de Mato Grosso do Sul (UFMS); mestre em Genética e Melhoramento pela Universidade Estadual de Londrina (UEL); doutora em Genética e Melhoramento pela Universidade Federal de Viçosa (UFV); formação para tutoria em Licenciatura em Biologia a Distância pela Universidade de Brasília (UnB); professora associada da UFMS.

${ }^{3}$ Graduada em Ciências Biológicas Bacharelado e Licenciatura pela Universidade Federal de Mato Grosso do Sul (UFMS); mestre em Genética e Biologia Molecular pela Universidade Estadual de Londrina (UEL); técnica em Web Designer pela Escola de Informática TREINATEC; professora assistente da Universidade Federal de Mato Grosso do Sul.

4 Graduado em Filosofia pela Faculdade Associadas do Ipiranga (FAI); mestre em Filosofia da Educação pela Pontifícia Universidade Católica de São Paulo (PUC-SP). Professor adjunto da UFMS.
} 
os pesquisados, $42,9 \%$ afirmaram que não poderiam fazer um curso presencial, de modo que a modalidade a distância atende aos objetivos de qualificação profissional para suas regiões e de inclusão social.

Palavras-chave: Educação a Distância, Graduação, Licenciatura em biologia, Qualificação profissional, Inclusão social

\section{Abstract:}

The Distance Education has appeared in ancient times, took shape through the printing press and obtained new meaning with the advent of the Internet. In 2006, UFMS and six universities constituted the Northern Consortium Degree in Biology, which aims to qualify lay teachers and social demand, in nine municipalities of Mato Grosso do Sul state. This study intends to outline these academics' profile. We've interviewed $154,71.1 \%$ of which were women and $29.9 \%$ men, most of them were 29 years old, had finished high school for more than10 years, were married, with children, and were working. Among women, the most part also kept the house. Among the interviewed $42.9 \%$ have said they could not take a classroom course, so this kind of course (distance one) meets the qualification targets in their regions and also social inclusion.

Keywords: Distance education, Graduation, Biology degree, Professional qualification, Social inclusion

\section{Breve histórico da Educação a Distância}

Embora não seja uma modalidade de ensino tão recente, nunca se falou tanto em Educação a Distância (EAD) como no momento. Por se tratar de um tema relativamente novo entre nós educadores, é de fundamental importância uma ampla discussão, com professores e gestores de todos os níveis de ensino, sobre as políticas públicas educacionais, no que diz respeito a programas dessa natureza (FREITAS; MAGALHAES, 2001).

A EAD é definida como uma modalidade de educação, na qual professores e alunos estão separados fisicamente no espaço e/ou no tempo. Essa é uma definição clássica que aparece na legislação brasileira e em diversos artigos (SANTO; RODRIGUES, 1999; NEVES, 2003; ALVES, 2011).

Castro-Filho et al. (2009) consideram que a EAD está embasada em linguagens das mídias (ou linguagens midiáticas), que podem ser entendidas como formas de representação particulares de cada mídia: linguagem manuscrita ou escrita com meios impressos; linguagem sonora como o rádio; e linguagem audiovisual com a televisão e o vídeo. Com o advento do computador e da Internet, que acaba reunindo muitos desses elementos, fala-se em linguagem multimidiática ou simplesmente multimídia. 
Nessa linha de pensamento, nos dias de hoje, a EAD está diretamente ligada ao desenvolvimento de novas tecnologias, podendo ser definida como uma prática educativa, em que o processo ensino-aprendizagem é mediatizado pelas tecnologias de comunicação e pelo professor, tutor ou orientador de aprendizagem (FREITAS; MAGALHAES, 2001).

Avaliando os conceitos de mídias, é fácil considerar que a Educação a Distância surgiu muito antes das modernas tecnologias de comunicação. Segundo Pimentel, Rossi e Vieira (2008), podemos considerar que ela apareceu quando as informações passaram a circular entre as pessoas sob a forma escrita, caracterizando um ensino por correspondência. Isso teria acontecido inicialmente na Grécia e depois em Roma, onde havia uma rede de comunicação que permitia o desenvolvimento significativo da troca de correspondências, que inauguraram uma nova era na arte de ensinar.

Para outros estudiosos, há necessidade de uma sistematização maior. Por isso, consideram como fundador da Educação a Distância o alemão Johannes Guttenberg, quando criou a escrita imprensa no século XV (ALVES, 2005). Em se tratando de educação, na evolução desse pensamento, o primeiro registro histórico de curso oferecido na modalidade a distância foi a proposta do professor Cauleb Phillips, que publicou, em 1728, em um jornal americano da cidade de Boston, uma propaganda convidando as pessoas a serem instruídas em taquigrafia, através de um curso por correspondência (ALVES, 2005; SARAIVA, 1996). Fato semelhante ocorreu no Brasil, em 1891, quando foi publicada a primeira edição do Jornal do Brasil, contendo, na seção de classificados, um anúncio oferecendo profissionalização em datilógrafo, também através de um curso por correspondência (ALVES, 2005; ALVES 2011).

No início do século XX, surgiram no Brasil escolas especializadas em ensino a distância. Em 1923, foi fundada a Rádio Sociedade do Rio de Janeiro, oferecendo a educação pelo rádio. Em 1936, foi doada ao Ministério da Educação e Saúde e, no ano seguinte, inaugurado o Serviço de Radiodifusão Educativa do Ministério da Educação (ALVES, 2011). A partir daí, várias experiências propostas tiveram grande sucesso, como os cursos ofertados, por exemplo, pelo Instituto Rádio-Monitor, a partir de 1939, e o Instituto Universal Brasileiro, após 1941, muitos deles com objetivo profissionalizante (ALVES, 2005; ALVES, 2011). 
Nas décadas de 1960 e 1970, além do material impresso, os cursos de Educação a Distância passaram a oferecer outras ferramentas didáticas, associando correio, rádio, áudio, vídeo, as transmissões de rádio e televisão e mais tarde o uso do computador (FREITAS; MAGALHÃES, 2001; ALVES, 2011; SARAIVA, 1996; PIMENTEL; ROSSI; VIEIRA, 2008). Os primeiros programas de rede surgiram nessa época. Foi criado, na estrutura do Ministério da Educação e Cultura, o Programa Nacional de Teleducação (Prontel), e, mais tarde, a Secretaria de Aplicação Tecnológica (Seat), a quem competia coordenar e apoiar a teleducação no Brasil (SARAIVA, 1996).

A evolução dos meios de comunicação permitiu a realização de cursos a distância através de rádio, televisão e filmes, mas tinha como principal limitação a ausência de diálogo entre alunos e professores, não permitindo assim a interação entre eles (BESERRA; BATISTA, 2014). Para Vygotsky (2007), a interação consiste na relação interpessoal com outros indivíduos, o contato com o outro social, que promoverá a internalização das formas culturalmente estabelecidas de organização do mundo, contribuindo para o desenvolvimento psicológico humano. Para tanto, a linguagem exerce um papel fundamental na comunicação e no estabelecimento de significados compartilhados.

Em função de todos esses aspectos, a EAD ganhou novo cenário na década de 1990, por meio do computador e a popularização da Internet, tornando possível a utilização de diversas ferramentas de interação, como correio eletrônico, participação em fóruns, salas de bate-papo virtuais, comunicação oral por meio de vídeo e webconferências, que permitem a participação de um número maior de pessoas, física ou temporalmente distantes, numa comunicação interativa, na qual todos podem interagir a qualquer momento, independente da sincronia de ações, e a veiculação de objetos de aprendizagem pela Internet (ABBAD; CARVALHO; ZERBINI, 2006; CASTRO-FILHO et al, 2009; COELHO, 2004; ESERRA; BATISTA 2014).

O apoio de novas tecnologias da comunicação e informação possibilitou a adoção de e-learning e blended learning, em grande escala, pelas universidades e instituições de ensino. Considera-se e-learning a aprendizagem apoiada por recursos da web, com combinação de mídias e tecnologias (vídeo, áudio, tecnologia multimídia, entre outras). A aprendizagem se dá de modo síncrono e assíncrono, 
com a disponibilização de materiais, os quais geralmente estão separados geograficamente uns dos outros. Já blended learning combina a aprendizagem face a face com a aprendizagem mediada pela Internet. Ocorrem também cursos híbridos, em que parte significativa das atividades de ensino-aprendizagem foram transferidas para ambientes on-line, requerendo o redesenho dos cursos e a redução do tempo gasto em sala de aula (ABBAD; CARVALHO; ZERBINI, 2006).

Incentivados pelas possibilidades decorrentes das novas Tecnologias da Informação e das Comunicações (TICs) e por sua inserção em todos os processos produtivos, cada vez mais cidadãos e instituições veem, nessa forma de educação, um meio de democratizar o acesso ao conhecimento e de expandir oportunidades de trabalho e aprendizagem ao longo da vida (NEVES, 2003).

Em 1889, William Harper profetizou que chegaria um dia em que o volume de instrução recebida por correspondência seria superior à ofertada no ensino presencial das escolas (PIMENTEL; ROSSI; VIEIRA, 2008). Ele só não fazia ideia de como a tecnologia ofereceria alternativas de distribuição do conhecimento, de forma tão rápida como ocorre atualmente. Hoje, diferentemente do que ocorria há apenas uma década, não é mais possível desconsiderar o impacto que a introdução da EAD on-line causou e certamente ainda ocasionará em nossas formas de conceber e de praticar a educação e a comunicação (BOHADANA; VALLE, 2009).

\section{A consolidação da Educação a Distância no Brasil}

A EAD tem sido uma presença constante nas agendas das políticas públicas educacionais brasileiras, desde a década de 1970, com as já citadas iniciativas dos programas por correspondência, rádio e televisão (FREITAS; MAGALHAES, 2001; CASTRO-FILHO et al, 2009).

Em 1992, foi criada a Coordenadoria Nacional e Educação a Distância na estrutura do MEC e, a partir de 1995, a Secretaria de Educação a Distância (SARAIVA, 1996). Do ponto de vista legal, a EAD foi consolidada no Brasil em 1996, através da Lei 9.394, a chamada Lei de Diretrizes e Bases da Educação Nacional (Ldben). Em seu artigo 80, ela estabelece que o "Poder Público incentivará o desenvolvimento e a veiculação de programas de ensino a distância, em todos os níveis e modalidades de ensino, e de educação continuada" (BRASIL, 1996). 
Nos anos seguintes, foram publicados decretos e portaria que especificavam instrumentos e procedimentos que deveriam ser adotados, pelas instituições, para obter o credenciamento junto ao MEC, permitindo a oferta de cursos de graduação a distância (PIMENTEL; ROSSI; VIEIRA, 2008).

O Decreto $\mathrm{n} . \underline{2}$ 2.404, de 10 de fevereiro de 1998, regulamentou o artigo 80 da Ldben, apresentando definições sobre Educação a Distância, estabelecendo normas para certificação, matrícula, transferência e aproveitamento de créditos, formas de avaliação e credenciamento de instituições que as realizem (BRASIL, 1998a).

No mesmo ano, o Decreto $\mathrm{n}$. - 2.561, de 27 de abril de 1998, alterou o decreto 2.404, anterior, em seu artigo 11, incluindo o credenciamento para instituições de educação profissional em nível tecnológico e, no artigo 12, ampliando a oferta de cursos a distância dirigidos à educação profissional de nível técnico (BRASIL, 1998b). Ainda em 1998, a Portaria n. 301, de 7 de abril de 1998, em 12 artigos, normatizou os procedimentos de credenciamento de instituições que quisessem oferecer cursos de graduação e de educação profissional tecnológica com a modalidade a distância (BRASIL, 1998c).

A regulamentação final da EAD da Lei $n^{\circ}$. 9.394, veio em 2005, através do Decreto $n^{\circ} .5 .622$, que, em seu artigo $1^{\circ}$, diz que a Educação a Distância

caracteriza-se como modalidade educacional na qual a mediação didáticopedagógica nos processos de ensino e aprendizagem ocorre com a utilização de meios e tecnologias de informação e comunicação, com estudantes e professores desenvolvendo atividades educativas em lugares ou tempos diversos. (BRASIL, 2005).

Nesse mesmo ano, foi criado o Sistema Universidade Aberta do Brasil (UAB), tendo como prioridade a formação de professores para a Educação Básica (UAB, 2009).

\section{O curso de Licenciatura em Biologia pelo Consórcio Setentrional em Mato Grosso do Sul}

O curso de Licenciatura em Biologia na modalidade a distância, pelo Consórcio Setentrional, surgiu como continuidade de ações de Instituições Públicas de Ensino Superior - Ipes - dos Consórcios Regionais Univir-CO, AMAZÔNIA NET e CONSÓRCIO BAHIA do Consórcio Nacional UniRede. Seu projeto pedagógico foi elaborado em 2005, em parceira com as seguintes Instituições Públicas de Ensino Superior (Ipes): Universidade de Brasília (UnB), Universidade Federal de Goiás 
(UFG), Universidade Federal de Mato Grosso do Sul (UFMS), Universidade Federal do Tocantins (UFT), Universidade Federal do Pará (UFPA), Universidade Estadual de Santa Cruz (Uesc), Fundação Universidade Federal de Rondônia (Unir) e Universidade Federal do Amazonas (Ufam). A UnB e UFG, em parceria com a Universidade Estadual de Goiás (UEG), e a UFMS, em parceria com a Universidade Estadual de Mato Grosso do Sul (UEMS)(ZANON et al., 2005) implantaram a primeira turma em 2006 (SÁ, 2007).

O Projeto Pedagógico do Curso foi elaborado levando em conta as Diretrizes Curriculares Nacionais para os Cursos de Biologia, a Resolução CNE/CP 2, de 19 de fevereiro de 2002, e os Referenciais de Qualidade para Cursos a Distância SEED/MEC, enfatizando a formação para o uso didático de Tecnologias de Informação e Comunicação - TIC (ZANON et al., 2005).

O objetivo principal do Consórcio Setentrional era oferecer qualificação profissional para os professores leigos, ou seja, que já estavam atuando no ensino fundamental e médio e necessitavam da titulação. Após avaliação de cada cidade polo, foram oferecidas vagas também para demanda social. Sendo assim, em Mato Grosso do Sul, foram oferecidas 325 vagas, sendo 75 destinadas para professores leigos e 250 para demanda social, distribuídas em nove municípios: Água Clara, Bela Vista, Camapuã, Chapadão do Sul, Jardim, Paranhos, Porto Murtinho, Rio Brilhante e São Gabriel do Oeste. Desses, as cidades de Bela Vista e Jardim foram atendidas por tutores da Universidade Estadual de Mato Grosso do Sul (UEMS) e os demais por tutores da UFMS (SÁ, 2007).

Em sua estrutura organizacional, cada polo contava com um tutor local e um tutor a distância. Praticamente, todos os tutores a distância da UFMS eram especialistas e, quando não o eram, foram assessorados por professores especialistas. As prefeituras locais participaram com a disponibilização da estrutura física, devendo a sede do polo contar com salas providas de computadores e biblioteca, onde os alunos podiam estudar e ser atendidos pelo tutor local. Também foi montado um laboratório de aulas práticas, que foi equipado aos poucos. As atividades a distância foram embasadas inicialmente na plataforma Teleduc e, posteriormente, ocorreu migração para a plataforma Moodle. Uma vez por mês, eram desenvolvidas atividades presenciais que contemplavam as avaliações 
escritas, aulas práticas e outras atividades didáticas, tais como: seminários, debates, dinâmicas de grupo etc. (Sá, 2007).

Embora tenham sido oferecidas 325 vagas, de acordo com Sá (2007), no processo seletivo, foram preenchidas 300 (trezentas). As vagas para professor leigo não foram completamente preenchidas. Das 75 vagas ofertadas, apenas candidatos foram classificados, correspondendo a $8 \%$ dos professores leigos que se pretendia atender. Não havendo número suficiente de professores leigos selecionados, as vagas remanescentes desse grupo foram preenchidas por candidatos da demanda social, de modo que, das 220 vagas destinadas a eles, foram classificados 294, com um acréscimo de 25,1\% (Tabela 1). Até o momento da pesquisa, o índice de evasão já era bastante alto $(38,7 \%)$, se comparado aos cursos presenciais.

No entanto, esse índice ficou bastante aquém do percentual de 62\%, citado por Maurício e Schlemmer (2014), em sua revisão de literatura sobre as causas da evasão na educação a distância. Dentre as causas referenciadas por elas estão: fatores situacionais, falta de apoio acadêmico, problemas com a tecnologia, falta de apoio administrativo, sobrecarga de trabalho, falta de disciplina para estudar e de autonomia necessária para acompanhar um curso a distância, falta de tempo para se dedicar aos estudos, desmotivação, demora do retorno dos tutores e dificuldades técnicas, rotatividade de tutores, carência de um modelo mental da modalidade a distância, crença de que cursos a distância requerem menos esforços, desconhecimento da prática da aprendizagem a distância, ausência de interatividade, problemas pessoais, perda de emprego, que representa a perda do acesso à Internet, desinteresse do tutor em responder em tempo hábil.

Apesar de todas as dificuldades enfrentadas, 61,3\% dos acadêmicos permaneciam no curso até o momento desta pesquisa. Consideramos que uma informação importante revelada é a de que 42,9\% dos acadêmicos afirmaram que, se o curso fosse presencial, não teriam possibilidade de fazê-lo. Além disso, 57,1\% afirmaram que, mesmo que pudessem frequentar o curso presencial, ele não era oferecido em sua cidade. Isso reforça a ideia de que os cursos a distância cumprem seu papel social de oferecer oportunidade de estudos para as pessoas que, por um motivo ou por outro, não podem cursar as graduações presenciais. 


\section{O perfil dos alunos de Licenciatura em Biologia pelo Consórcio Setentrional em Mato Grosso do Sul}

Observa-se uma grande variedade de perfis de alunos de cursos a distância. Em cursos de graduação, predominam os jovens, enquanto, em cursos de especialização e pós-graduação, nota-se uma variação maior de idade entre os estudantes (ABBAD; CARVALHO; ZERBINI, 2006).

Nossa pesquisa teve como objetivo principal caracterizar o perfil dos alunos de Licenciatura em Biologia pelo Consórcio Setentrional em Mato Grosso do Sul, fornecendo dados básicos para outras pesquisas que permitam avaliar o sucesso do projeto como um todo. Para tal, foi elaborado um questionário visando a coletar o maior número de dados possível, que apresentamos em anexo. Quando a coleta de dados foi efetuada, os acadêmicos estavam cursando o módulo $V$, equivalente ao $5^{\circ}$ semestre de um curso presencial. A pesquisa abrangeu questionamentos como: sexo, idade, tempo de conclusão do ensino médio, características familiares e profissionais, local de residência e acesso físico ao polo e aos instrumentos didáticos, além de aspectos gerais relacionados às dificuldades encontradas para o aprendizado. Os questionários foram aplicados pelos tutores de cada polo, durante atividades presenciais, em junho de 2009.

$O$ perfil dos alunos que cursaram Licenciatura em Biologia/EAD/UFMS é muito diferente dos que estão no ensino presencial. Enquanto esses últimos são em sua maioria jovens, egressos diretamente do ensino médio, solteiros, sem filhos e ainda amparados pelos pais, ou seja, sem necessidade de trabalhar, os acadêmicos do ensino a distância são normalmente mais velhos, casados, com filhos e que trabalham, pelo menos, oito horas diárias, por cinco dias na semana. 
Tabela 1: Dados referentes ao curso de Licenciatura em Biologia oferecido pelo Consórcio Setentrional, em sete cidades polo de Mato Grosso do Sul, com início em 2007.

\begin{tabular}{|c|c|c|c|c|c|c|c|c|c|}
\hline \multirow[b]{2}{*}{ Polo } & \multicolumn{2}{|c|}{ Vagas - professores leigos } & \multicolumn{2}{|c|}{ Vagas - demanda social } & \multicolumn{2}{|c|}{ Total de vagas } & \multicolumn{3}{|c|}{ Alunos } \\
\hline & Oferecidas & Preenchidas & Oferecidas & Preenchidas & Oferecidas & Preenchidas & Frequentando & Pesquisados & $\begin{array}{c}\% \text { de } \\
\text { pesquisados }\end{array}$ \\
\hline Água Clara & 5 & 2 & 20 & 23 & 25 & 25 & 16 & 12 & 75,0 \\
\hline Bela Vista & 5 & 1 & 20 & 13 & 25 & 14 & 13 & 7 & 53,8 \\
\hline Camapuã & 5 & 0 & 20 & 25 & 25 & 25 & 14 & 14 & 100,0 \\
\hline Chapadão do Sul & 10 & 0 & 40 & 41 & 50 & 41 & 22 & 20 & 90,9 \\
\hline Jardim & 10 & 0 & 15 & 25 & 25 & 25 & 12 & 9 & 75,0 \\
\hline Paranhos & 7 & 3 & 33 & 37 & 40 & 40 & 27 & 18 & 66,7 \\
\hline Porto Murtinho & 10 & 0 & 15 & 25 & 25 & 25 & 21 & 19 & 90,5 \\
\hline Rio Brilhante & 13 & 0 & 47 & 60 & 60 & 60 & 33 & 31 & 93,9 \\
\hline São Gabriel do Oeste & 10 & 0 & 40 & 45 & 50 & 45 & 26 & 24 & 92,3 \\
\hline Total & 75 & 6 & 250 & 294 & 325 & 300 & 184 & 154 & 83,7 \\
\hline
\end{tabular}

Revista Educação Online, n. 19, jun-ago 2015, p. 166-201 
Dos 184 alunos que frequentavam o curso em 2009, 154 responderam ao questionário, correspondendo a $83,7 \%$ dos alunos. A pesquisa mostrou que $47,4 \%$ deles desejavam anteriormente fazer o curso de ciências biológicas. Os demais o estavam fazendo, porque não tiveram oportunidade de fazer o curso de sua preferência, porque foram estimulados por outras pessoas ou, após avaliação, consideraram uma boa oportunidade (figura 1). No entanto, todos afirmaram que buscavam, com o curso, uma forma de melhorar sua qualificação profissional.

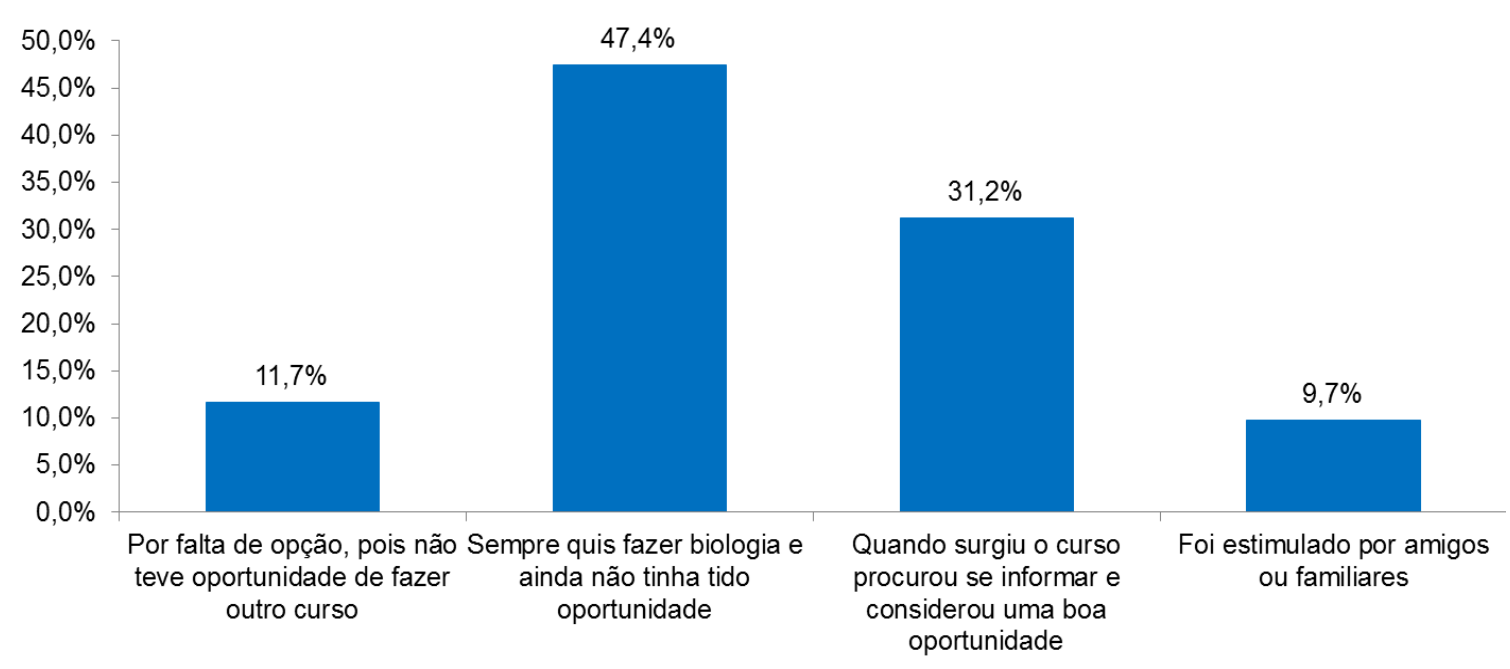

Figura 1. Distribuição por explicação dos motivos que estimularam os acadêmicos à escolher o curso de Licenciatura em Biologia à distância/ Consórcio Setentrional.

Para efeito de comparação, foi realizada uma pesquisa rápida quanto a alguns aspectos relacionados aos alunos de graduação em ciências biológicas presencial do CCBS (Centro de Ciências Biológicas e da Saúde) da UFMS, cursando $3^{\circ}$ e $4^{\circ}$ ano: idade, sexo, estado civil, número de filhos e participação no mercado de trabalho.

Uma diferença marcante entre os acadêmicos do curso presencial e a distância é que, dentre os primeiros, apenas 1,2\% conciliam trabalho e estudo, enquanto que dentre os acadêmicos do curso de EAD, 87,7\% trabalham, sendo $100 \%$ dos homens e $82,4 \%$ das mulheres. A maior parte deles, $60,4 \%$, são funcionários públicos. Os demais trabalham para empresas $(24,8 \%)$ ou são autônomos (11,2\%). A grande maioria dos acadêmicos, 56,7\%, tem jornada de trabalho de 6 a 8 horas diárias, 37,3\% afirmaram que essa jornada ultrapassa 8 horas diárias, e 34,3\% desses trabalham pelo menos um período no sábado. 
Além disso, 27,6\% costumam levar serviço para casa. Também perguntamos se quando precisavam estudar se havia possibilidade de troca de horários, $41 \%$ respondeu que não existia essa possibilidade, e $23,9 \%$, somente às vezes.

De acordo com os relatos, o principal fator que levou à procura pelo curso, para $57,1 \%$ dos entrevistados, foi o fato de não haver em sua cidade outro curso de seu interesse. No entanto, o dado mais importante é que 42,9\% afirmaram que se o curso fosse presencial não teriam possibilidade de fazê-lo. Esse é um dado muito importante, uma vez que o objetivo principal do ensino a distância é ampliar a possibilidade de atender a estudantes que não podem frequentar regularmente o ensino presencial e introduzir novas concepções de tempo e espaço em educação, inclusive alunos portadores de necessidades especiais, hospitalizados, encarcerados, residentes em áreas de difícil acesso à escola e ou universidade (FREITAS; MAGALHAES, 2001; CASTRO-FILHO et al, 2009).

Quanto à idade, o curso de ciências biológicas presencial apresentou $98,8 \%$ de seus alunos com idade inferior a 28 anos, enquanto as turmas de EAD foram bastante heterogêneas nesse aspecto, com uma proporção maior de alunos com idade entre 29 e 39 anos (Figura 2).

Ferreira et al. (2007) traçaram, em sua pesquisa, o perfil dos estudantes de EAD. Dentre os pontos convergentes ao exposto na presente pesquisa, estão a idade, a maioria dos alunos com mais de 30 anos, e o estado civil, a maioria dos alunos é casada. 


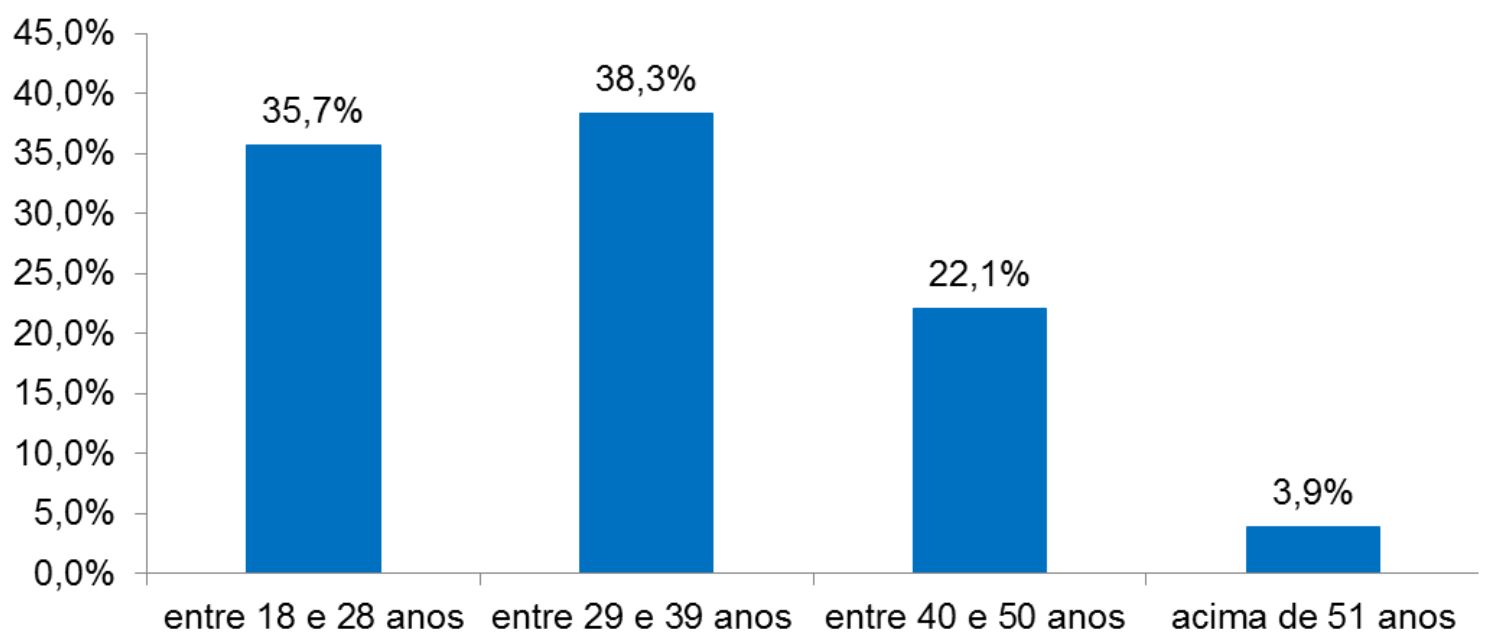

Figura 2. Distribuição por idade dos acadêmicos do curso de Licenciatura em Biologia a distância/ Consórcio Setentrional

Como consequência dessa grande variabilidade de idades, era de se esperar que muitos deles estivessem há muito tempo sem estudar, o que de fato constatamos (Figura 3). Observe que, somando as faixas dos acadêmicos que concluíram o ensino médio entre 11 e 20 anos e há mais de 20 anos, chegamos a um total de $28,5 \%$, que estavam afastados dos bancos escolares há pelo menos 11 anos.

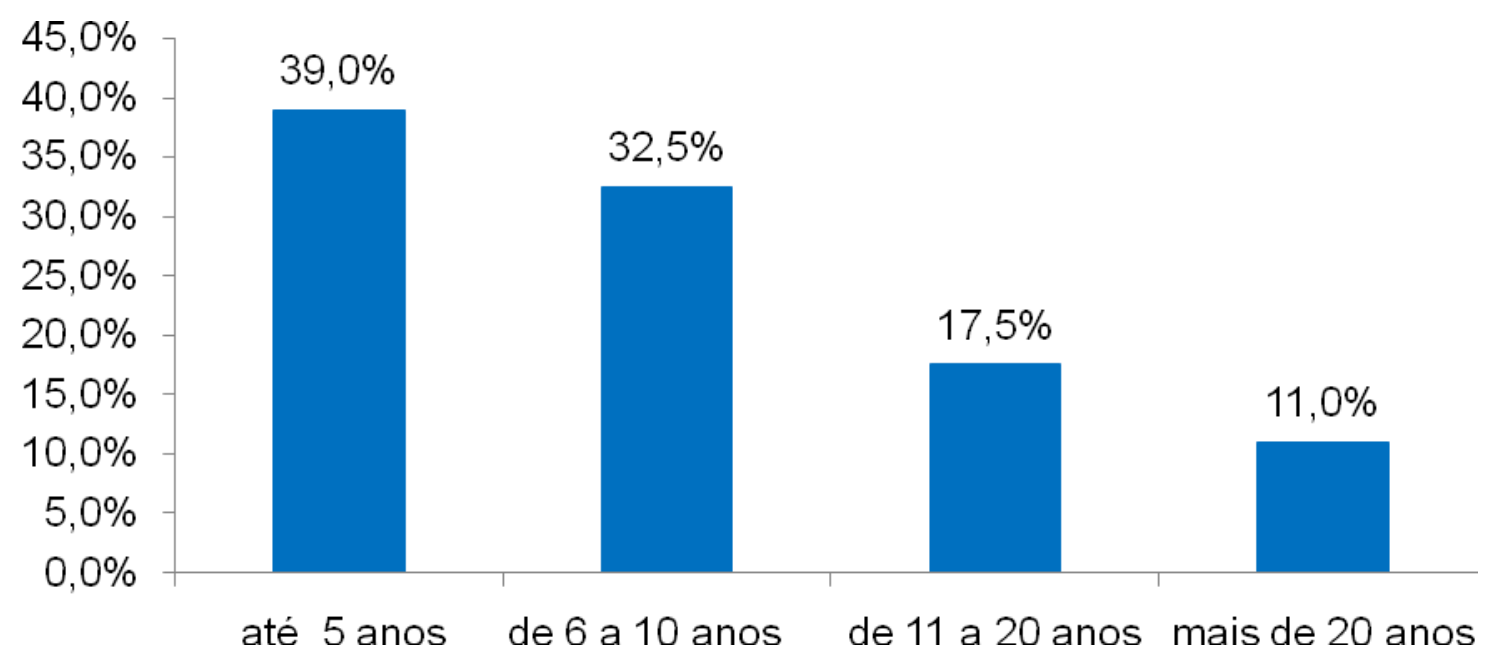

Figura 3. Distribuição por tempo de conclusão do ensino médio dos acadêmicos do curso de Licenciatura em Biologia a distância/Consórcio Setentrional 
Dentre os acadêmicos da Biologia/EAD, 23\% deles haviam iniciado outra graduação, mas não concluíram. Foram cursos em diversas áreas, incluindo ciências biológicas. Por outro lado, 6,5\% já haviam concluído outra graduação: química, medicina veterinária, agronomia, letras, administração, economia, pedagogia e até um caso de ciências biológicas na modalidade bacharelado, na qual o acadêmico busca agora a habilitação para lecionar. Os demais possuíam apenas o ensino médio.

Dentre os alunos pesquisados, $29,9 \%$ são de sexo masculino e $70,1 \%$ do sexo feminino. Essa proporção é semelhante à observada no curso presencial de ciências biológicas do Centro de Ciências Biológicas e da Saúde (CCBS) da UFMS, no qual 32,9\% são de sexo de masculino e $67,1 \%$ de sexo feminino.

Sobre essa maior presença feminina nos cursos estudados, Passos (2000 apud ABREU, 2014), afirma que

as profissões ditas femininas são [...] aquelas que comportam uma extensão do domínio social de seus papéis de mães; como educadoras encarregadas de transmitir o patrimônio cultual, e, como servidoras, devotadas ao serviço de outros. (p.6)

Ainda nesse contexto, Fagundes (2002) aponta que:

Grande parte de estudos sobre a educação feminina tem evidenciado a estreita ligação entre o ser mulher e a escolha de cursos com conteúdos humanísticos, que convergem para profissões tipificadas socialmente como femininas, como o ser professora dos anos iniciais ou das áreas das ciências humanas e sociais. (p.233)

A predominância de mulheres entre os alunos de cursos a distância nas instituições formadoras não chega a ser uma novidade, nem mesmo na comparação com os cursos presenciais. Elas são maioria em quase todos os recortes, com mais de $56 \%$ do total, um percentual muito semelhante ao já verificado nas pesquisas anteriores do Censo EAD. BR de 2010, 2011 e 2012. (Censo, 2014).

No que se refere ao estado civil, há também uma grande diferença entre os dois cursos comparados. O curso de ciências biológicas presencial apresentou $98,8 \%$ de seus alunos solteiros, enquanto os acadêmicos da Biologia/EAD casados ou com união estável corresponderam a $63,0 \%$, dentre 
eles, $86 \%$ têm filhos (figura 4). Além disso, dentre as mulheres solteiras, 33\% também possuem filhos.

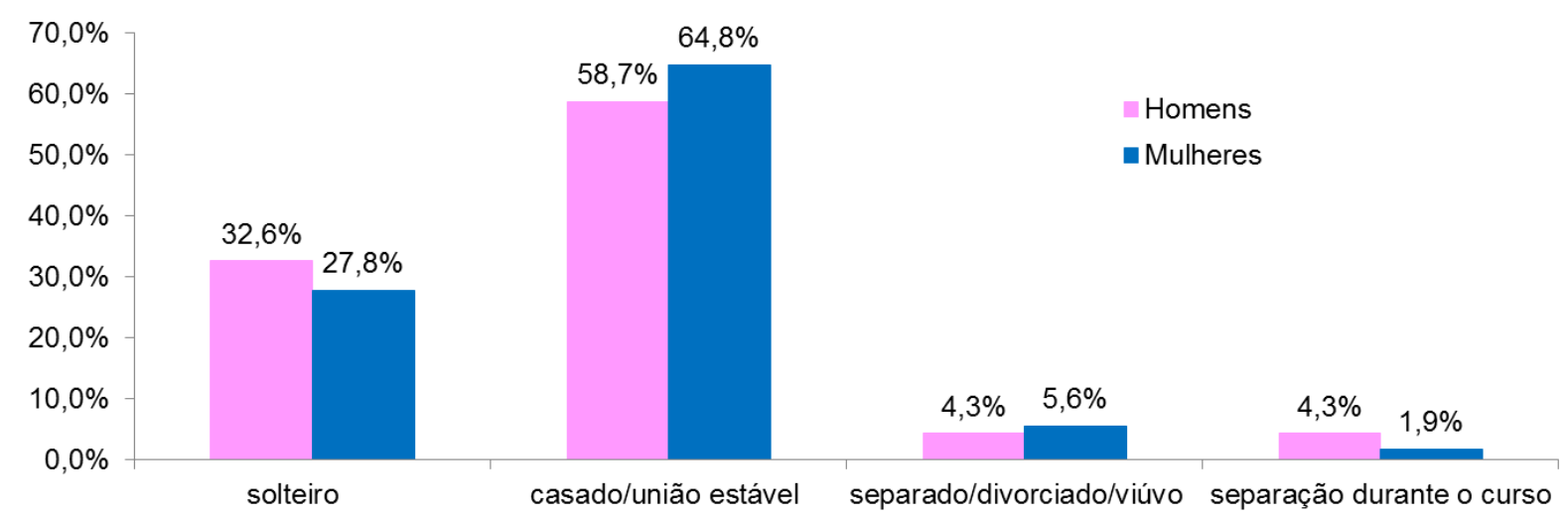

Figura 4. Distribuição por estado civil dos acadêmicos do curso de Licenciatura em Biologia à distância/ Consórcio Setentrional

A idade implica em outros aspectos importantes. Em função do fato de muitos serem casados, conciliando trabalho e estudo, é de se esperar que tenham um maior envolvimento com os afazeres domésticos que os mais jovens. Em nossa cultura, na qual as atividades domésticas ainda são normalmente realizadas pelas mulheres, esperava-se que elas tivessem mais envolvidas com isso, o que foi de fato constatado. Quando perguntamos a cada acadêmico quem era responsável pelas atividades domésticas em sua casa, incluindo se dividia esse serviço com outra pessoa ou se havia um funcionário para isso, $13 \%$ dos homens informaram que faziam o serviço doméstico, sem ajuda de outra pessoa. Já no caso das mulheres esse percentual foi de $70,4 \%$ (figura 5).

Luz (2013) destaca a importância de conhecer a divisão sexual do trabalho, para ajudar a compreender o fenômeno da grande procura das mulheres pela EAD, mostrando que, historicamente, a divisão sexual do trabalho atribui aos homens a produção e às mulheres a reprodução e a educação das crianças. Por outro lado, a autora aponta que, mesmo após a entrada da mulher no mercado de trabalho, as atividades domésticas e cuidados com os filhos continuam sendo atribuições femininas, o que acaba gerando jornada dupla - trabalho e casa.

Nesse contexto, a sobrecarga de trabalho da mulher acaba restringindo o tempo dispensado à formação superior, que é de extrema importância, uma 
vez que prepara para o mercado de trabalho, que trata com desigualdade homens e mulheres. Luz (2013) procurou demonstrar que a condição de gênero das mulheres de baixa renda é que as torna público majoritário da EAD.

Soares (2002) discute que o aumento da matrícula feminina na universidade é um processo crescente e de transformação no Brasil, que pode também ser observado na Educação a Distância. Ferreira et al. (2007) afirmam que esse novo modelo de educação facilita e auxilia milhares de mulheres que têm jornada dupla, o que torna mais difícil frequentar um curso presencial, que requer muito mais tempo disponível e tem atividades presenciais diárias.

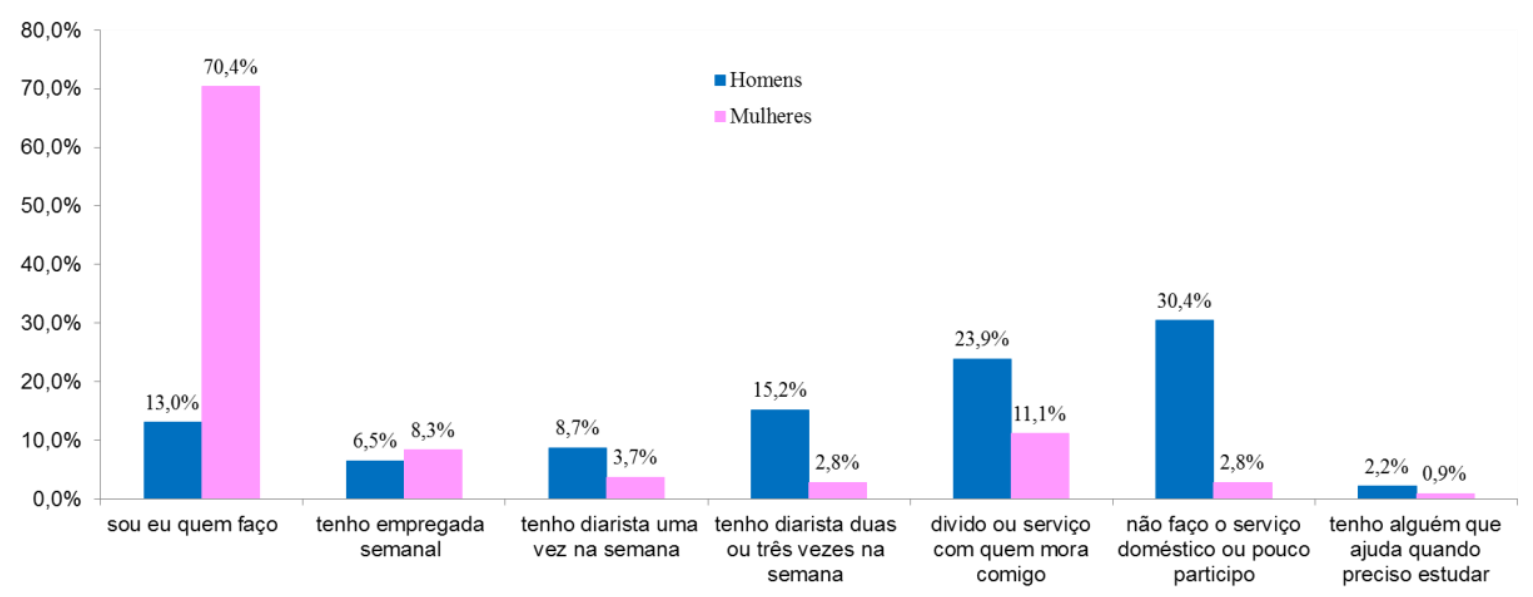

Figura 5. Distribuição por grau de envolvimento com atividades domésticas, por homens e mulheres, alunos do curso de Licenciatura em Biologia à distância/ Consórcio Setentrional

Outro aspecto que questionamos foi o das relações pessoais, se essas foram afetadas a partir do momento que ingressaram no curso. $77,8 \%$ dos homens e $66,8 \%$ das mulheres disseram ter total apoio da família para estudar. No entanto, quando perguntamos se tiveram alguma desavença familiar ocasionada pelos estudos, $28,9 \%$ dos homens e $53,7 \%$ das mulheres afirmaram ter tido algum problema desse tipo. Entre os homens, 8,9\% tiveram problemas com suas parceiras, e 2,2\% com filhos. No caso das mulheres, esse percentual foi de $34,3 \%$ para problemas com cônjuges e 4,6\% com filhos. Três entre as 108 mulheres pesquisadas, informaram que se separaram de seus companheiros depois que iniciaram o curso, e duas delas afirmaram que esse fato foi parcialmente influenciado pelo estudo. 
Infelizmente, as dificuldades enfrentadas pelas acadêmicas não é exclusiva das que estão no ensino a distância. Almeida (2000) observa que a educação tradicional nos lares e escolas, durante muito tempo, privilegiou 0 sexo masculino, sendo a educação formal considerada supérflua para as mulheres. Essa deveria se dedicar às suas atribuições de cuidado da família e dos filhos. Ainda hoje, essa visão traz consequências para as relações entre os casais, que se traduzem pela subordinação feminina ao sexo masculino, numa escala social hierarquizada.

O acesso ao ambiente de estudo é também muito importante. Ao avaliarmos as necessidades de deslocamento dos alunos, constatamos que a grande maioria reside na área urbana da cidade-polo onde estão matriculados; $14,1 \%$ residem na área rural, mas boa parte com acesso através de estradas pavimentadas. Apenas $1,2 \%$ precisam se deslocar por 50 ou mais $\mathrm{km}$ até chegar ao polo, e alguns por estradas de terra ruins (Figura 6). $O$ fator distância do polo é extremamente importante, uma vez que os moradores da área rural têm maior dificuldade para acompanhar todas as atividades desenvolvidas no polo.

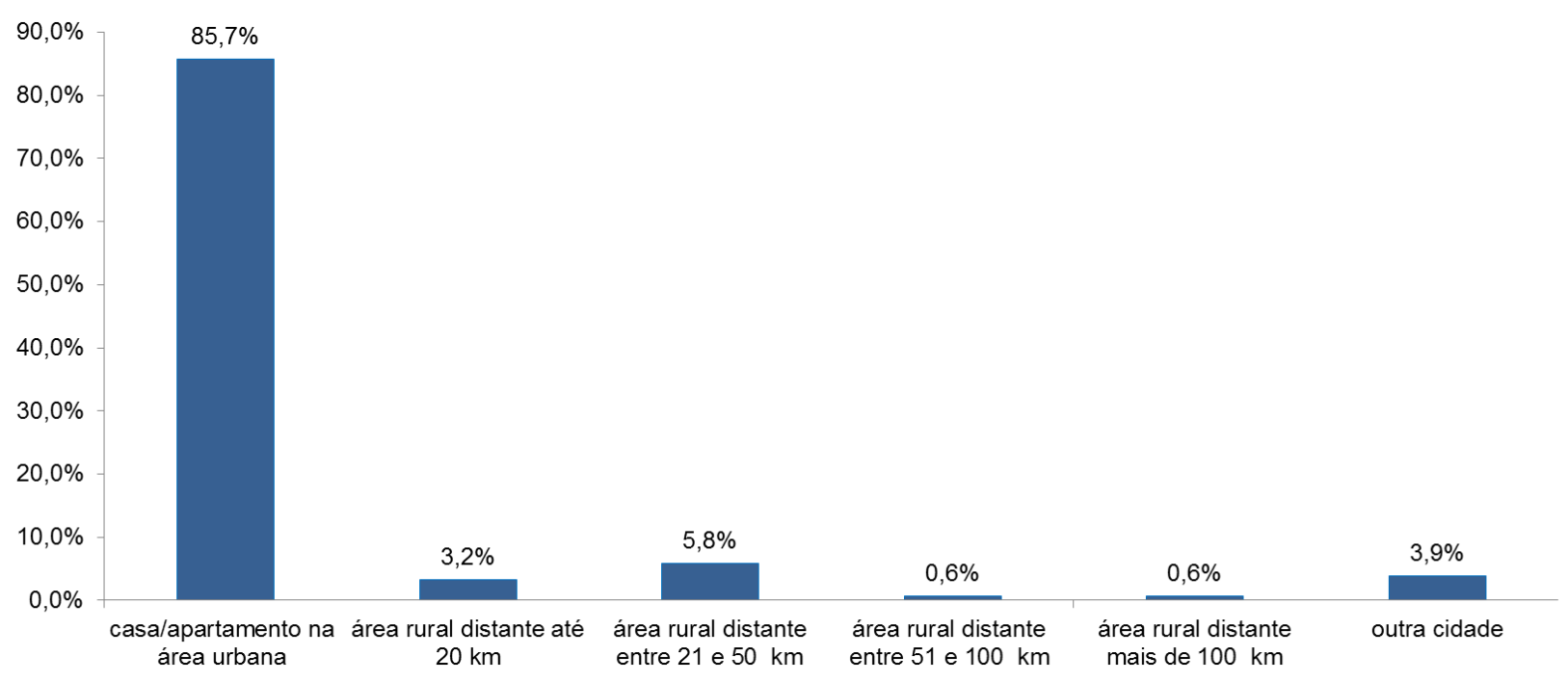

Figura 6. Distribuição por local de residência dos acadêmicos do curso de Licenciatura em Biologia à distância/Consórcio Setentrional.

Em decorrência do fato de grande parte dos alunos residirem na cidade polo, a maioria deles, $85,7 \%$, levam até uma hora para se deslocar até o local 
das aulas, de modo que o deslocamento não é um problema que interfere no desempenho deles (figura 7 ).

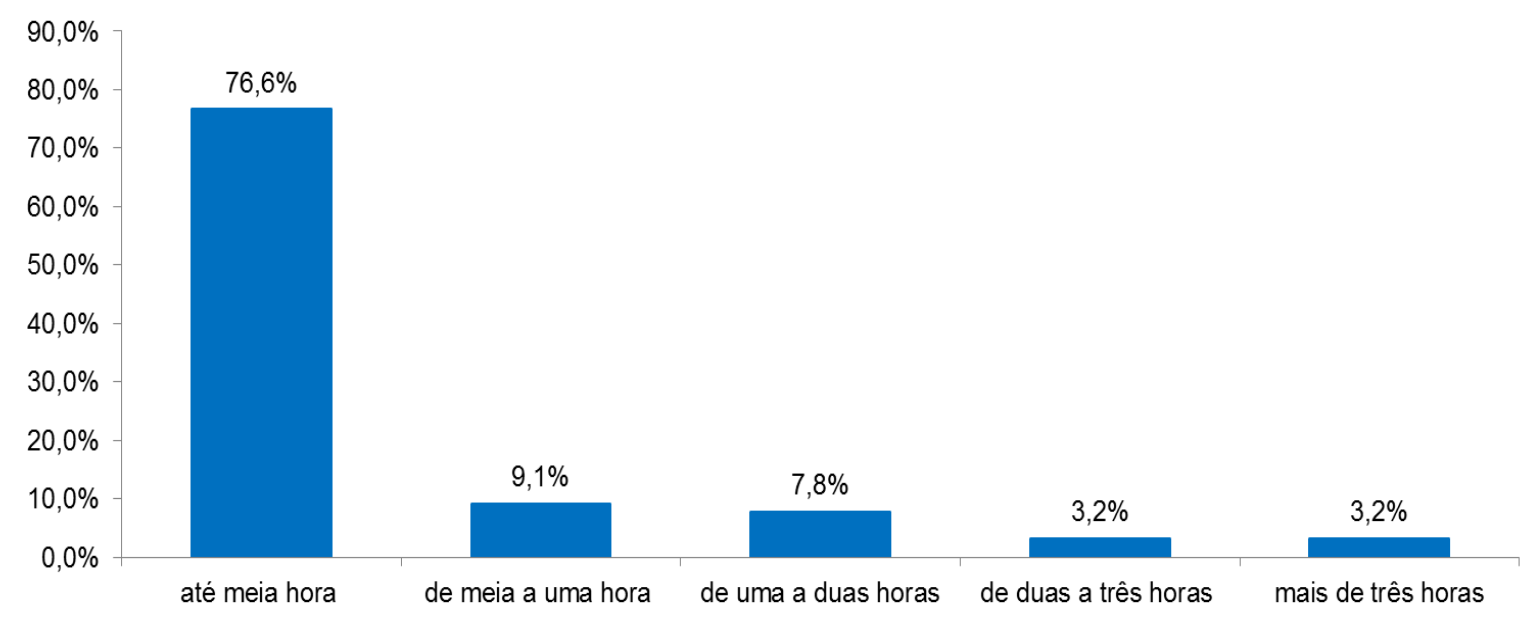

Figura 7. Distribuição por tempo de deslocamento entre suas residências e o polo de estudo dos acadêmicos do curso de Licenciatura em Biologia a distância/Consórcio Setentrional.

Imaginamos ainda que, além de todos esses comprometimentos externos, como família e trabalho, o acesso ao computador é um fator importante e que deve interferir diretamente no desempenho dos estudantes. Entre eles, 64,8\% afirmaram possuir computador em casa, embora em alguns casos esse acesso não esteja sempre disponível. Aqueles que têm maior dificuldade de acesso, como os que utilizam no trabalho ou na casa de outra pessoa, em poucas oportunidades, somam $9,7 \%$. Os $5,2 \%$ que alegam usar 0 computador do polo, em poucas oportunidades, são principalmente aquelas que moram em locais mais distantes (Figura 7). Já a estrutura de oferta de computadores nos polos parece estar atendendo a contento, uma vez que nenhum aluno fez reclamações quanto $a$ isso. A figura 9 mostra em detalhe $o$ local de uso do computador e as circunstâncias de facilidade ou dificuldade. 


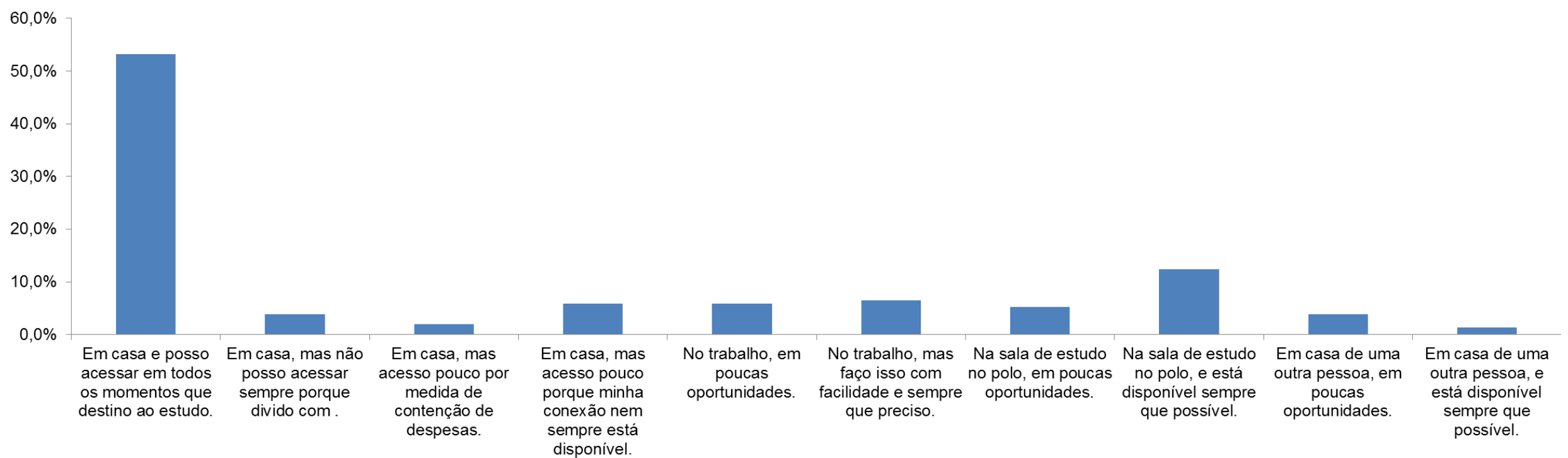

Figura 8. Distribuição por acesso dos acadêmicos do curso de Licenciatura em Biologia a distância ao computador, Universidade Federal de Mato Grosso do Sul/Consórcio Setentrional.

Revista Educação Online, n. 19, jun-ago 2015, p. 166-201 
Embora as informações quanto ao acesso ao polo não mostrem grandes dificuldades por parte dos acadêmicos, apenas 50,6\% afirmam participar sempre das atividades oferecidas pelo tutor local (figura 9). Esse deve se constituir num fator que interfere no desempenho daqueles que alegam ter dificuldade na condução do curso.

Apesar de a principal característica da educação a distância ser o fato de os professores e estudantes estarem distantes no espaço e no tempo, muitos estudiosos chamam a atenção para o fato de que essa não é a única característica importante. Essa distância força 0 aluno a construir conhecimento, fazendo com que ele desenvolva competências, habilidades, atitudes e hábitos relativos ao estudo, à profissão e à sua própria vida, no tempo e local que the são adequados, atuando ora a distância, ora em presença física ou virtual, e com o apoio de sistemas de gestão e operacionalização específicos, bem como de materiais didáticos intencionalmente organizados, apresentados em diferentes suportes de informação, utilizados isoladamente ou combinados, e veiculados através dos diversos meios de comunicação (NEVES, 2003).

Diante dessa postura diferenciada, os professores podem propor questões para pesquisa teórica ou para a discussão e solução de situações problemas. As ferramentas da tecnologia da informação possibilitam trocas contínuas de conhecimento entre professor e aluno, diminuindo a necessidade de aulas meramente expositivas e tornando o aluno mais ativo no processo de busca do conhecimento. Seu uso permite, por exemplo, que alunos de diferentes localidades possam colaborar para a realização de um projeto comum (SILVA et al., 2007). 


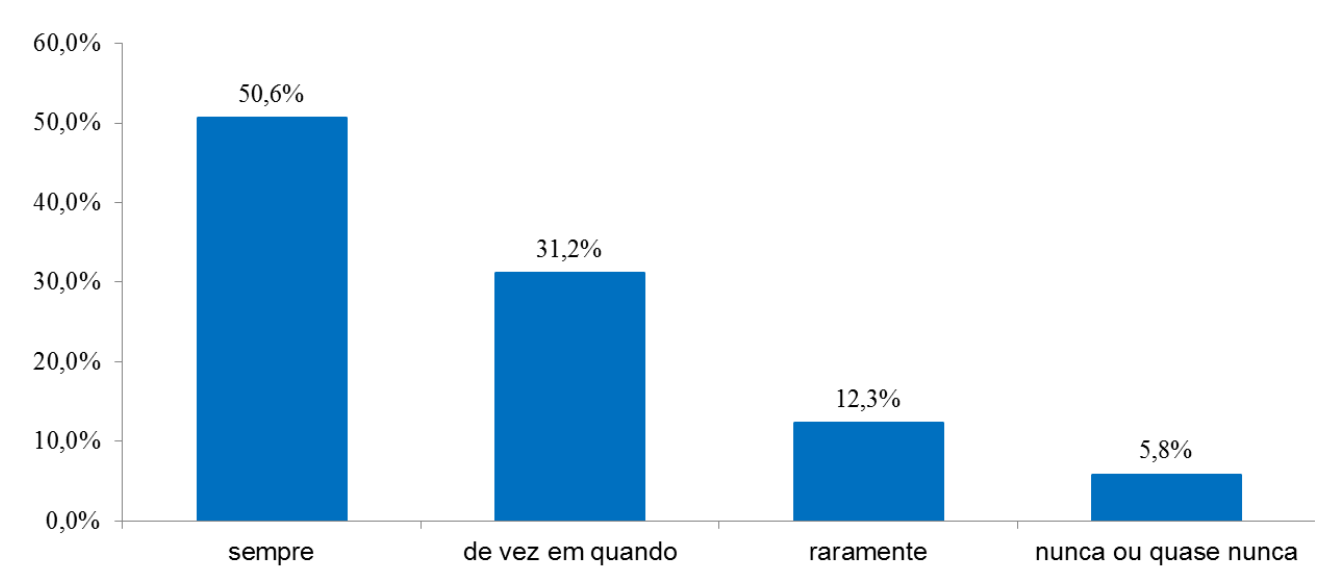

Figura 9. Distribuição por frequência de participação nas atividades de apoio com o tutor local, dos acadêmicos do curso de Licenciatura em Biologia à distância/Consórcio Setentrional.

Entretanto, o principal fator que interfere no desempenho dos acadêmicos, com certeza são as horas destinadas ao estudo. Estudiosos indicam que a dedicação ao estudo diário deve ser de três a três horas e meia, semelhante à média do tempo de duração das aulas diárias de um curso presencial que funcione em um único período (BEVILACQUA, 2009). Levando em consideração que o aluno dedique ao estudo três horas diárias, cinco vezes por semana, esse totalizaria 15 horas de estudo semanais. Levando isso em consideração, de acordo com o que informaram os acadêmicos do curso, somente $14,8 \%$ deles estariam dedicando horas suficientes para o aprendizado (Figura 10).

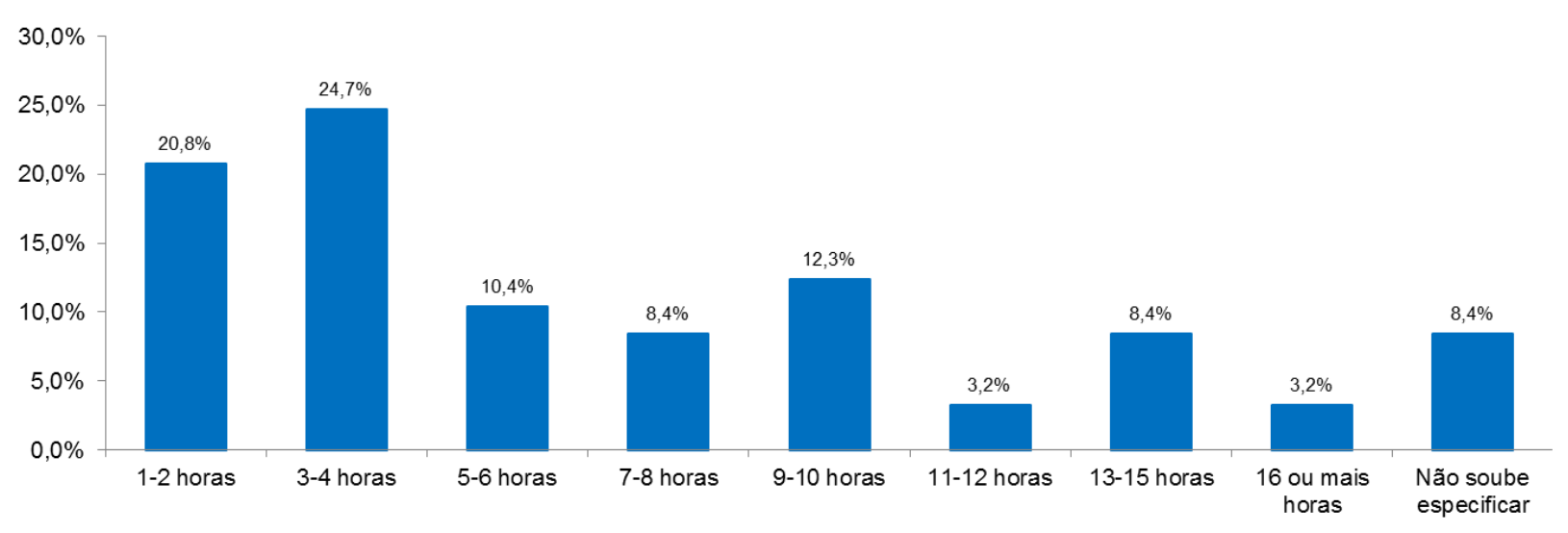

Figura 10. Distribuição por quantidade de horas semanais destinadas ao estudo pelos acadêmicos do curso de Licenciatura em Biologia a distância, Universidade Federal de Mato Grosso do Sul/Consórcio Setentrional. 
As demais responsabilidades já citadas, relacionadas a trabalho e família, muitas vezes, inviabilizam a participação do aluno em encontros síncronos durante o dia. No Brasil, observou-se que alunos de cursos a distância, principalmente em treinamentos corporativos não obrigatórios e em cursos técnicos abertos ao público, costumam acessar os websites dos cursos à noite (das 18 à meia-noite) e nos finais de semana (ABBAD; ZERBINI; SOUZA, 2010).

Alguns estudiosos enfatizam que o aspecto humano do estudante é um indicador de permanência e efetivação da aprendizagem. A Educação a Distância possibilita autonomia e independência de aprendizagem ao aluno (CASTRO et al., 2005; ABBAD, 2007), mas, por outro lado. exige a capacidade de se organizar no sentido de se dedicar ao estudo de forma sistemática. O estudante deve ser gradativamente autônomo, e autonomia é algo que se constitui ao longo da vida. É fundamental que o professor/orientador seja o intermediário desse amadurecimento e da construção da autonomia pelo estudante (LIMA; SILVA; PAIVA, 2010)

Para isso, é necessário possuir um ambiente favorável ao estudo: um lugar e horário adequados, bom estado de saúde, física e psíquica, e ambiente sociofamiliar equilibrado (ALVES; NOVA, 2003; PIMENTEL; ROSSI; VIEIRA, 2008; CASTRO et al., 2005; ABBAD, 2007).

Quanto ao grau de dificuldade, apenas 6,5\% dos acadêmicos afirmaram ter passado com facilidade nos módulos cursados, em contraposição a 59,7\%, que disseram ter tido dificuldades em todos os módulos. Além disso, houve diferenças significativas no grau de dificuldade entre acadêmicos de sexo masculino. Os que tiveram dificuldades em todos os módulos equivalem a $39,1 \%$ dos acadêmicos do sexo masculino e $68,5 \%$ do sexo feminino (Figura $11)$. 


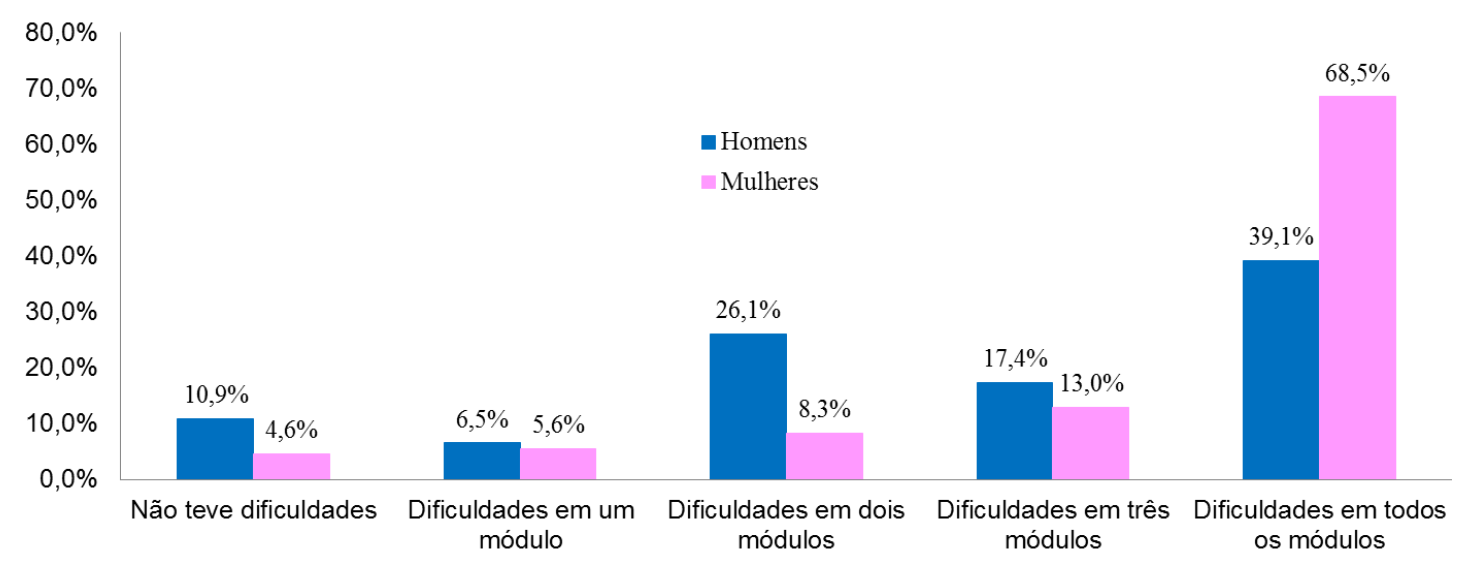

Figura 11. Distribuição por número de módulos em que tiveram dificuldades, levando em consideração quatro módulos concluídos, dos acadêmicos do curso de Licenciatura em Biologia a distância, Universidade Federal de Mato Grosso do Sul/Consórcio Setentrional.

Quando perguntamos aos acadêmicos, o que eles consideravam como principais fatores responsáveis pelas dificuldades por eles enfrentadas, 0 aspecto mais citado foi o fato de não se lembrarem dos conteúdos do ensino médio. O segundo fator mais citado foi a dificuldade de encontrar momentos para estudar, em função do envolvimento com trabalho. Em sequência, 49 alunos alegaram ficar nervosos na hora da prova e não conseguir desenvolvêla a contento e, empatado, com 43 citações, está o fato de terem dificuldade de concentração para estudar; os que estudam muito, mas esquecem com facilidade (Tabela 2).

Tabela 2. Motivos alegados pelos acadêmicos do curso de Licenciatura em Biologia a distância, Universidade Federal de Mato Grosso do Sul/Consórcio Setentrional, para explicar suas dificuldades e baixo desempenho.

\section{Motivos de dificuldade/baixo desempenho}

Homens Mulheres

não consigo aprender com uma estrutura de curso a distância, em que existem poucas aulas presenciais participo pouco de estudos em grupo $17,4 \% \quad 30,6 \% \quad 26,6 \%$ participo pouco das atividades com o tutor local falto muito as atividades presenciais que ocorrem $21,7 \% \quad 27,8 \% \quad 26,0 \%$ $30,4 \% \quad 31,5 \% \quad 31,2 \%$ tenho dificuldade de entendimento, porque não me lembro do que estudei no ensino médio tenho dificuldades em entender a linguagem de livros de modo geral

$13,0 \% \quad 8,3 \% \quad 9,7 \%$

tenho dificuldades em escrever as minhas respostas em atividade e provas

$23,9 \% \quad 38,9 \% \quad 34,4 \%$

tenho dificuldade de entender os conteúdos na forma que esses são apresentados no livro utilizado

$10,9 \% \quad 11,1 \% \quad 11,0 \%$
estudo muito, mas não consigo gravar por muito tempo -

\begin{tabular}{rrr}
$8,7 \%$ & $4,6 \%$ & $5,8 \%$ \\
\hline $19,6 \%$ & $21,3 \%$ & $20,8 \%$ \\
$8,7 \%$ & $36,1 \%$ & $27,9 \%$
\end{tabular}


até o dia da prova já esqueci

fico nervoso na hora das provas e não consigo fazer -

tenho os famosos "brancos"

$8,7 \% \quad 41,7 \% \quad 31,8 \%$

envolvo-me com atividades de trabalho e não consigo

estudar

envolvo-me com atividades domésticas ou familiares e não consigo estudar

tenho dificuldade de concentração: começo a estudar e me distraio com algum fator externo

$34,8 \% \quad 32,4 \% \quad 33,1 \%$

$21,7 \% \quad 23,1 \% \quad 22,7 \%$

não tenho o apoio que preciso de familiares

$30,4 \% \quad 26,9 \% \quad 27,9 \%$

nos momentos de folga, priorizo atividades sociais, como

festas e passeios, e acabo não estudando

$2,2 \% \quad 7,4 \% \quad 5,8 \%$

por timidez ou inibição, não entro em contato com o tutor

local para sanar minhas dúvidas

$26,1 \% \quad 13,0 \% \quad 16,9 \%$

$4,3 \% \quad 11,1 \% \quad 9,1 \%$

Dos 43 que alegam estudar muito, mas que apesar disso têm dificuldade em guardar as informações, 34 estão entre aqueles que afirmaram ter tido dificuldade em todos os módulos já cursados. No entanto, desses 34, apenas sete alunos informaram dedicar ao estudo a quantidade de horas recomendadas para o aprendizado.

Dentre os 16 acadêmicos de sexo masculino que informaram ter tido dificuldades em todos os módulos, apenas um (6,25\%) informou estudar 15 ou mais horas semanais. Levando em consideração que 15 horas correspondem a três horas de estudo diárias, cinco dias por semana, observamos também aqueles que estudam pelo menos oito horas, que equivaleria a duas horas diárias de estudo, considerando-os como os que se aproximam do ideal. Estão nessa faixa mais três acadêmicos. Os quatro têm em comum estarem na mesma faixa etária, entre 40 e 50 anos, serem casados, trabalharem pelo menos oito horas diárias, cinco dias na semana. Eles acreditam que o principal fator que os leva a ter dificuldades de aprendizagem é o fato de terem terminado o ensino médio há muito tempo.

Já para as 72 acadêmicas que informaram ter tido dificuldades em todos os módulos, sete $(9,72 \%)$ afirmaram estudar 15 ou mais horas semanais. As que estudam pelo menos oito horas são $13,18,01 \%$. Diferente do que poderíamos imaginar, as que estudam mais, com exceção de uma, são casadas ou solteiras com filhos, trabalham oito horas diárias, cinco dias na semana, além de cuidarem dos afazeres domésticos. A principal reclamação delas também é a dificuldade de se lembrarem do que estudaram no ensino 
médio, uma vez que somente uma delas está na faixa de 29 a 39 anos. As demais estão acima de 40 anos e uma delas acima de 51 .

Pelo que pudemos perceber, os alunos consideram que a forma como os conteúdos estão apresentados no livro dificultam o aprendizado. O livro texto do módulo 1, por exemplo, foi denominado "O contexto da vida". As unidades exploram os constituintes químicos e físicos do ambiente e dos seres, a origem da vida e do pensamento científico, enquanto a educação é contextualizada historicamente e no mundo atual. Mas não existem disciplinas separadas. Isso que deveria ser um elemento facilitador constitui-se em dificuldade, porque o aluno não foi educado dessa forma em sua história escolar. Mesmo para os que estudaram mais recentemente, apesar das recomendações dos estudiosos em educação de haver uma interação maior entre conteúdos de diversas áreas e com a realidade, os livros escolares ainda tratam as disciplinas como estanques (KRASILCHICK; MARANDINO, 2007).

Quando os estudiosos avaliam a qualidade dos livros didáticos, percebem que a maioria deles ainda não modificou 0 habitual enfoque ambiental fragmentado, estático, antropocêntrico, sem localização espaçotemporal. Tampouco substituíram um tratamento metodológico, que concebe o aluno como ser passivo, depositário de informaçõesdesconexas e descontextualizadas da realidade (MEGID-NETO; FRACALANZA, 2003).

Segundo Castro et al (2005), para o sucesso do modelo de Educação a Distância, é essencial que a tecnologia e os materiais didáticos utilizados permitam a comunicação ativa entre todos os participantes do ambiente, e que todos os envolvidos no processo sejam capazes de se adaptar a ele. No entanto, não temos elementos para afirmar que as dificuldades dos alunos quanto ao material didático seja única e exclusivamente em função do estilo modular. Para afirmarmos isso, seria necessária uma avaliação criteriosa do material, o que não foi feito neste trabalho.

Também é elemento essencial para o sucesso da Educação a Distância a atuação do tutor, porque cabe a ele, além de auxiliar o aluno no estudo, motiválo, para que ele deixe de ser passivo e mero receptor de informações e passe a sujeito que produz conhecimento (LACERDA; ESPÍNDOLA, 2013; PIMENTEL; ROSSI; VIEIRA, 2008), atitude necessária para o estudante de Educação a Distância. Um número expressivo de alunos (31,2\%) associou suas 
dificuldades ao fato de participarem pouco das atividades junto ao tutor presencial. Apenas três alunos de um dos polos fizeram críticas à atuação de um tutor local, mas este trabalho não coletou elementos suficientes para avaliação dos tutores. Entretanto, com certeza, a formação de profissionais preparados para atuar em EAD é uma preocupação constante em muitos trabalhos (BOHADANA; VALLE, 2009). O sucesso de um programa educacional, quer presencial quer a distância, está relacionado ao empenho dos participantes e, sobretudo à condução dos coordenadores, instrutores e às condições de acompanhamento oferecidas aos estudantes (FREITAS, 1995).

O resultado final do curso foi uma taxa de evasão geral de $51 \%$, variando entre $28 \%$ a $68 \%$ dependendo de cada polo, conforme podemos observar na figura 12.

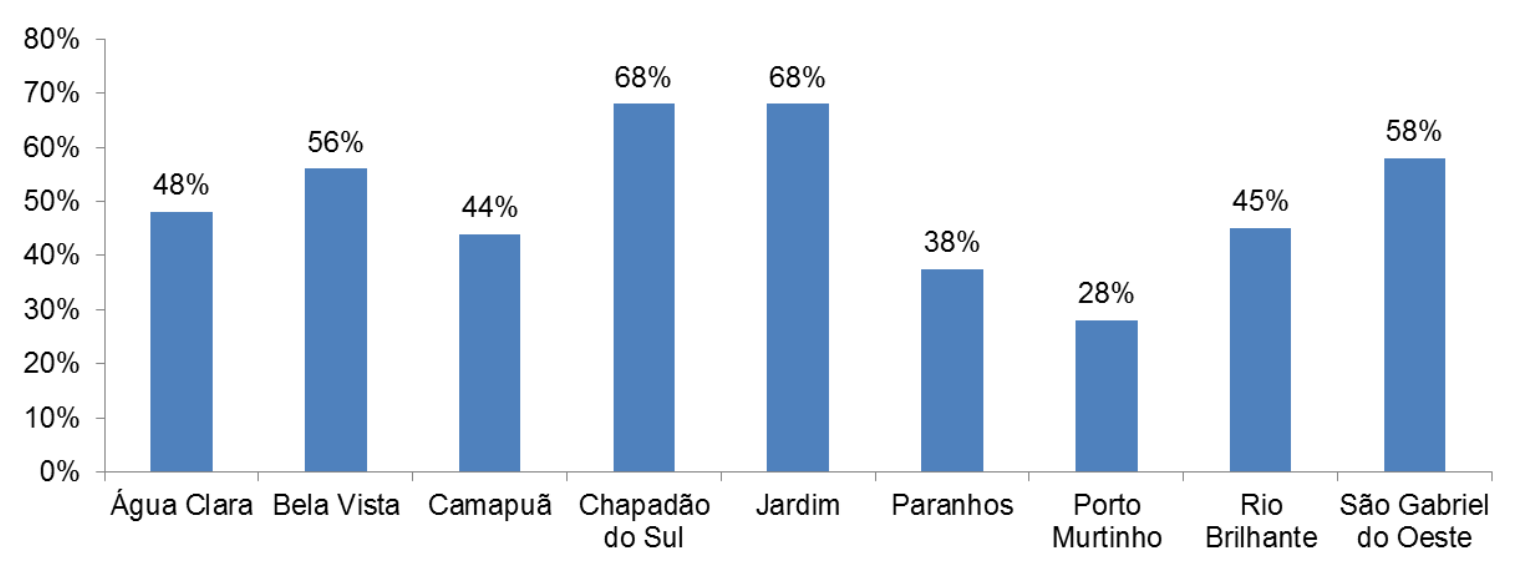

Figura 12. Resultado final do grau de evasão do curso de Licenciatura em Biologia a distância, Universidade Federal de Mato Grosso do Sul/Consórcio Setentrional.

Pesquisas mostram que a evasão é um fator frequente em cursos a distância, e que o êxito depende de programas bem definidos, material didático adequado, professores capacitados e conjugação de meios apropriados a facilitar a interatividade, em conformidade com a realidade dos alunos a serem atendidos (COELHO, 2004; MARTINS; CRUZ, 2008). Por isso, todos esses fatores podem e devem ser avaliados em pesquisas futuras, com o objetivo de aprimorar o processo. A própria UAB (2009) afirma que, em todos esses programas, muitos aspectos ainda se encontram em adaptação.

Por outro lado, o governo tem feito sua parte. Com a finalidade de valorizar o magistério e apoiar a iniciação à docência de estudantes de 
licenciatura plena das instituições federais e estaduais de educação superior, a Coordenação de Aperfeiçoamento de Pessoal de Nível Superior (Capes) instituiu, por meio da Portaria $n^{\circ} 122$, o Programa Institucional de Bolsa de Iniciação à Docência (Pibid/2009). O programa, agora sob responsabilidade da Capes, visa a aprimorar a formação dos docentes e contribuir para elevação do padrão de qualidade da educação básica. O Pibid atenderá prioritariamente à formação de docente para ensino fundamental e médio. No ensino médio, serão prioridades as licenciaturas, dentre elas a biologia (CAPES, 2009).

\section{Considerações finais}

A partir da presente análise, foi possível concluirmos que a Educação a Distância é um meio eficaz e democrático de expansão do conhecimento. Por meio dela, uma gama enorme de pessoas podem se beneficiar da conquista de uma profissão.

No entanto, é importante considerarmos que ainda se fazem necessárias a implementação de estratégias para manter o aluno no curso e melhorar sua formação. Dentre essas estratégias, está a orientação do estudante sobre a importância da sua real participação para obtenção de uma educação de qualidade, o que refletirá, diretamente, na sua capacitação para a vida profissional e social. Outra visão fundamental a ser transmitida ao recémingresso em um curso a distância, é a disposição de comprometimento de parte do seu tempo às inúmeras atividades do curso, pois ainda é preciso que se desmistifique a maior facilidade dos cursos de EAD em relação aos tradicionais presenciais.

Muitos dos acadêmicos, principalmente as mulheres, além de estudar, são ainda responsáveis pelas atividades domésticas. Em função de todos esses fatores e envolvimentos externos, são pessoas que têm muita dificuldade em organizar um cronograma diário de estudo, conforme o recomendado, sendo esse o principal fator que os leva a ter grande dificuldade de aprendizado. Não podemos nos esquecer ainda daqueles que residem nas áreas rurais e que, por esse ou outros motivos, têm dificuldade de acesso aos momentos presenciais e ao computador.

Vale lembrar que é mais proveitoso encararmos Educação a Distância como uma expressão idiomática que significa, na verdade, educação 
independente de distâncias (NEVES, 2003), e que a boa vontade dos governantes, associada aos avanços tecnológicos obtidos nas últimas décadas, nos permitem vislumbrar um futuro, em que a informação, bem como as diversas formas como ela será trabalhada e distribuída, estabelecerão novas relações entre povos e nações (CACIQUE, 2009). Essa pode ser desenvolvida em diversa modalidades, como e-learning, blended learning e cursos híbridos, como citado na introdução desse estudo (ABBAD; CARVALHO; ZERBINI, 2006).

A demanda pela Educação a Distância cresce a cada dia, para atender às exigências de um mundo em mudanças aceleradas e com menor disponibilidade de tempo e espaços formais para a educação (SALES, 2008). Essa pode ser considerada a mais democrática das modalidades de educação, pois, se utilizando de tecnologias de informação e comunicação, transpõe obstáculos à conquista do conhecimento. Essa modalidade de educação vem ampliando a sua colaboração para a ampliação da democratização do ensino e a aquisição dos mais variados conhecimentos, principalmente por se constituir em um instrumento capaz de atender a um grande número de pessoas simultaneamente, chegar a indivíduos que estão distantes dos locais onde são ministrados os ensinamentos e/ou que não podem estudar em horários préestabelecidos.

O governo federal criou leis e estabeleceu normas para a Educação a Distância no Brasil (UNIFESP, 2009) e até os cursos superiores da Educação a Distância apresentam diplomas com equivalência aos dos cursos oferecidos pelas instituições de ensino superior que utilizam a modalidade presencial. Isso mostra que a modalidade de Educação a Distância está rompendo barreiras, criando um espaço próprio e complementando a presencial.

Embora haja grande preocupação por parte da população, corroboramos com a ideia de Freitas e Magalhães (2001), de que a Educação a Distância não veio para substituir o ensino presencial, e sim se tornarem aliadas no desenvolvimento dos cidadãos. A EAD, cada vez mais, toma lugar de destaque ao lado do ensino presencial, sendo um importante caminho para a formação e atualização de profissionais em serviço, podendo incorporar todas as possibilidades tecnológicas de comunicação, presencial e a distância. 
Entretanto, embora avanços importantes tenham acontecido nos últimos anos, consideramos que ainda há um longo caminho a percorrer, para que a Educação a Distância possa ocupar um espaço de destaque no meio educacional, em todos os níveis, vencendo todos os preconceitos.

\section{Referências bibliográficas}

ABBAD, Gardênia da Silva; CARVALHO, Renata Silveira; ZERBINI, Thaís. Evasão em curso via Internet: explorando variáveis explicativas. RAEeletrônica, v. 5, n. 2, Art. 17, jul-dez 2006.

; ZERBINI, Thaís; SOUZA, Daniela Borges Lima de.

Panorama das pesquisas em educação a distância no Brasil. Estud. psicol. v.15, n.3, p 291-298, 2010.

Educação a distância: o estado da arte e o futuro necessário. Revista do Serviço Público (Brasília), v. 58, p. 100-110, 2007.

ABREU, Janete Maria França de. Gênero e Educação a Distância: uma apreciação a respeito da inserção das mulheres nos cursos de graduação da UFMA. São Paulo: ABED - Associação Brasileira de Educação a Distância Textos em EAD. 2014. Disponível em: <_www.abed.org.br/hotsite/20ciaed/pt/anais/pdf/81.pdf> Acesso em: 22/01/2015.

ALMEIDA, Jane Soares de. As lutas femininas por educação, igualdade e cidadania. Revista Brasileira e Estudos Pedagógicos, v.81, n.197, p. 5-13, janabr 2000.

ALVES, João Roberto Moreira. Educação a distância e as novas tecnologia de informação e aprendizagem. Dia-a-dia Educação - Portal Educacional do Estado do Paraná. 2005. Disponível em: <http://www.diadiaeducação.pr.gov.br/cidadania/arquivos/image/conteudo/artig os-teses/EAD/INFORMACAO.pdf >. Acesso em: 22/03/2015.

ALVES, Lucineia. Educação a distância: conceitos e história no Brasil e no mundo. Revista Brasileira de Aprendizagem Aberta e a Distância, v.10, p. 8392, 2011.

ALVES, Lynn; NOVA, Cristiane. Educação a Distância: limites e possibilidades. In: __ (Orgs). Educação a Distância: uma nova concepção de aprendizado e interatividade. São Paulo: Futura, 2003. p.1-23.

BESERRA, Patrícia de Fátima Costa; BATISTA, Keila Moreira. Perfil dos egressos em formação pedagógica a distância em ciências biológicas da Universidade Federal do Vale do São Francisco. REVASF - Revista de Educação do Vale do São Francisco, v.4, n.6, p. 253-268, dez 2014.

BEVILACQUA, Mariana. Aprender à distância requer disciplina. Educação a distância. SENAC/Paraná, 2009 . Disponível em: <http://www.pr.senac.br/noticias/?tppublic=Not\%C3\%ADcia\&numpubl=3190\&a no=2009 $>$. Acesso em: 22/06/2015. 
BOHADANA, Estella; VALLE, Lílian do. O quem da educação a distância. Revista Brasileira de Educação, v. 14, n. 42, p. 551, 2009.

BRASIL. Decreto No 5.622, de 19 de dezembro de 2005. Regulamenta o art. 80 da Lei no 9.394, de 20 de dezembro de 1996, que estabelece as diretrizes e bases da educação nacional. Diário Oficial da União, Brasília, 20/12/2005. Disponível em: <portal.mec.gov.br/sesu/arquivos/pdf/portarias/dec5.622.pdf>. Acesso em: 22/01/2015.

BRASIL. Lei No 9.394, de 20 de dezembro de 1996. Estabelece as diretrizes e bases da educação nacional. 1996. Diário Oficial da União, Brasília, 23/12/1996. Disponível em: $<$ http://www.Portal.mec.gov.br/arquivos/pdf/ldb.pdf.> Acesso em: 22/01/2015.

BRASIL. MINISTÉRIO DA EDUCAÇÃO. Portaria n.․ 301, de 7 de abril de 1998, Normatiza os procedimentos de credenciamento de instituições que queiram oferecer cursos de graduação e de educação profissional tecnológica com a modalidade a distância. 1998c. Diário Oficial da União, Brasília, 09/04/1998. Disponível em: <portal.mec.gov.br/.../arquivos/pdf/tvescola/leis/port301.pdf > Acesso em: 22/01/2015.

BRASIL. MINISTÉRIO DA EDUCAÇÃO. Decreto n.․ 2.494, de 10 de fevereiro de 1998. 1998a. Diário Oficial da União, Brasília, 11/02/1998. Disponível em: $<$ http://portal.mec.gov.br/seed/arquivos/pdf/tvescola/leis/D2494.pdf>. Acesso em: 22/01/2015.

BRASIL. MINISTÉRIO DA EDUCAÇÃO. Decreto $n . .2 .561$, de 27 de abril de 1998. Altera a redação dos arts. 11 e 12 do Decreto n.o 2.494,de 10 de fevereiro de 1998, que regulamenta o disposto no art. 80 da Lei n. 9.394 , de 20 de dezembro de 1996. 1998b. Diário Oficial da União, Brasília, 28/04/1998. Disponível em: <portal.mec.gov.br/seed/arquivos/pdf/tvescola/leis/D2561.pdf>. Acesso em: 22/01/2015.

BRASIL. Secretaria de Educação Fundamental. Parâmetros Curriculares Nacionais: ciências naturais. Brasília: MEC/SEF, 1998d. Disponível em: $<$ portal.mec.gov.br/seb/arquivos/pdf/livro04.pdf>. Acesso em: 22/01/2015.

CACIQUE, Ademir. $O$ ensino presencial e via Internet: uma experiência comparativa em educação a distância. Disponível em:

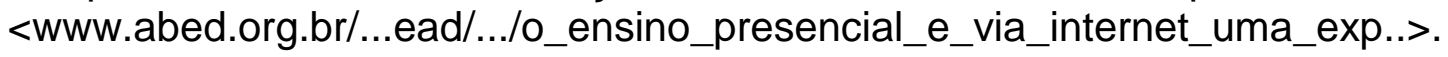
Acesso em 01/06/2015.

CAPES - Coordenação de Aperfeiçoamento de Pessoal de Nível Superior. Parecer № 122, de 16 de setembro de 2009. Dispõe sobre o Pibid - Programa Institucional de Bolsa de Iniciação à Docência, no âmbito da Capes. Diário Oficial da União, Brasília, n. 179, p. 47-48, 18 de setembro 2009. Seção 1.

Castro, Nivalde José , Haguenauer, C., Silva, E. M., Alves, L. A., Washington, M. G. M., Carvalho, M. B. O estudo a distância com apoio da internet. São Paulo: ABED - Associação Brasileira de Educação a Distância Textos em EAD. 2005. Disponível em:

<http://www.abed.org.br/site/pt/midiateca/textos_ead/683/2005/11/o_estudo_a_ distancia_com_apoio_da_internet> Acesso em: 14/07/2015. 
CASTRO-FILHO, José Aires de et al. Linguagens midiáticas e comunicação em EaD. Em Aberto, v. 22, n.79, p. 47-58, 2009.

CENSO, EaD.br. Relatório analítico da aprendizagem a distância no Brasil 2013. São Paulo: Pearson Education do Brasil, 2014.

COELHO, Maria de Lurdes. A evasão nos cursos de formação continuada de professores universitários na modalidade de educação a distância via Internet. São Paulo: ABED - Associação Brasileira de Educação a Distância Textos em EAD. $2004 . \quad$ Disponível em: < http://www.abed.org.br/site/pt/midiateca/textos_ead/626/2004/12/a_evasao_nos _cursos_de_formacao_continuada_de_professores_universitarios_na_modalid ade_de_educacao_a_distancia_via_internet_>. Acesso em: 15/07/2015.

FAGUNDES, Tereza Cristina Pereira Carvalho. Gênero e escolha profissional, In: FERREIRA, Silvia Lucia; NASCIMENTO, Enilda Rosendo. Imagens da mulher na cultura contemporânea. Salvador: UFBA/NEIM, 2002. p. 233 - 245.

FERREIRA, Zuleika Nunes; MENDONÇA, Gilda Aquino de Araújo; MENDONCA, A. F. O perfil do aluno de educação a distância no Ambiente teleduc. In: CONGRESSO BRASILEIRO DE EDUCAÇÃO À DISTÂNCIA, 2007. Anais... 2007. p. 1-10.

FREITAS, Katia Siqueira de. Importância da tele-educação na capacitação de professores. Revista Tecnologia Educacional, v.22, p.123-124, 1995.

; MAGALHÃES, Ligia Karam Corrêa de. Educação

a Distância - Educação aqui, ali e acolá - ontem, hoje e amanhã. GERIR, v.7, n. 20, p.11-54, 2001.

KRASILCHICK, M.; MARANDINO, M. Ensino de ciências e cidadania. $2^{2}$ ed. São Paulo: Moderna, 2007.

LACERDA, Fátima Kzam Damaceno de; ESPÍNDOLA, Romário de Macedo. Evasão na Educação a Distância: um estudo de caso. Revista Científica em Educação a Distância, v.3, n. 1, p.96-108, 2013.

LIMA, Jamile de Moura; SILVA, Cláudia Virgínia A. Prazim da; PAIVA, Clotilde Miranda de. Autonomia em educação a distância: relatos a partir da prática de tutoria na disciplina fundamentos psicológicos da educação em dois cursos de licenciatura da UFPBVIRTUAL. Disponível em <CVAP da Silvaii, CM de Paivaiii - abed.org.br>. Acesso em: 03/06/2015

LUZ, Luciane da. Mulheres e EaD: Uma análise de gênero sobre o perfil dos acadêmicos(as) na educação a distância no Brasil. Maiêutica, v.1, n.1, 2013. Disponível em:

$<$ https://publicacao.uniasselvi.com.br/index.php/SES/article/view/607>. Acesso em: 22/06/2015.

MARTINS, A. S.; CRUZ, D. M. A EAD nas licenciaturas UFSC/UAB: um estudo comunicação e das interações na disciplina de Introdução a Educação a distância. Contemporanea, v. 6, n. 2, p. 1-31, 2008.

MAURíCIO, Wanderléa Pereira Damásio; SCHLEMMER, Eliane. Educação a distância: as causas da evasão, os não lugares e suas manifestações. In: CONGRESSO BRASILEIRO DE ENSINO SUPERIOR A DISTÂNCIA - ESUD, XI, 2014, Florianópolis. Anais... Florianópolis: UNIREDE, 2014, p. 2023- 2033. 
Disponível em: <esud2014.nute.ufsc.br/anais-esud2014/files/pdf/127009.pdf>. Acesso em: 14/06/2015.

MEGID NETO, Jorge.; FRACALANZA, Hilário. O livro didático de ciências: problemas e soluções. Ciência \& Educação, v.9, n.2, p. 147-157, 2003.

NEVES, Carmen Moreira de Castro. Referenciais de qualidade para cursos à distância. Brasília: MEC - Ministério da Educação; Secretaria de Educação a distância, 2003.2 Disponível em: $<$ portal.mec.gov.br/seed/arquivos/pdf/ReferenciaisdeEAD.pdf>. Acesso em: 22/05/2015.

PIMENTEL, Nara Maria; ROSSI, Leila Lisiane; VIEIRA, Cristiano Costa Argemon. $E A D$, tecnologia e formas de linguagem. Campo Grande: UFMS, 2008.

SÁ, Antônio Lino Rodrigues de. Relatório de implantação: curso de Licenciatura de Biologia à distância. Campo Grande: Coordenadoria de Educação Aberta e a Distância; Universidade Federal de Mato Grosso do Sul, 2007.

SALES, A. M. Os desafios da Educação a distância. Portal Educação. Disponível em: <http://www.portaleducacao.com.br/educacao/>. Acesso em: 26 fev. 2009.

SANTOS, Eduardo Toledo; RODRIGUES, Marcos. Educação A Distância conceitos, tecnologias, constatações, presunções e recomendações. São Paulo: Edusp, 1999.

SARAIVA, T. Educação a distância no Brasil: lições da história. Em Aberto, v.16, n.70, p. 16-27, 1996.

SEGENREICH, Stella Cecilia Duarte. Desafios da educação a distância ao sistema de educação superior: novas reflexões sobre o papel da avaliação Educa em Revistar, n. 28, p. 161-177, 2006.

SILVA, Maria Auricélia da et al. Criação e Acompanhamento de Projetos Colaborativos no Ambiente SOCRATES. In: CONGRESSO DA SBC, XXVII, 2007, Rio de Janeiro. Anais... Rio de Janeiro: 2017, p. 305-313. Disponível em: $<$ http://www.br-ie.org/pub/index.php/wie/article/view/932>. Acesso em jun. 2015.

SOARES, Maria Susana Arrosa . Os principais atores da educação superior no Brasil. In: SOARES, A. Olive. Educação superior no Brasil. Brasília: Capes, 2002. p.145-171 Disponível em:

<http://www.dominiopúblico.gov.br/download/texto/me002311.pdf.>. Acesso em: 16/07/2015.

SOUZA, Lourivan Batista de. Educação superior a distância. O perfil do "novo" aluno sanfranciscano. Revista Brasileira de Educação Aberta e a Distância, v.11, artigo 2, 2012.

TRIVELATO, S. A experiência de ensino para a cidadania. Em Aberto, v.11, n. 55, p. 70-73, 1992.

UAB. Universidade Aberta. Disponível em: http://uab.capes.gov.br/index.php?option=com content\&view=article\&id=111\&lt emid=27. Acesso em: 26/05/2015. 
UNIFESP Virtual. Educação a Distância: fundamentos e guia metodológico. 2009. Disponível em <http:// www.virtual.epm.br/home/resenha.htm>. Acesso em: 28/02/2015.

VYGOTSKY, Lev Semyonovich. A formação social da mente. $2^{2}$ ed. São Paulo: Martins Fontes, 2007.

ZANON, Ângela Maria et al. Projeto pedagógico - licenciatura em biologia a Distância. $2005 . \quad$ Disponível em $<$ www.site.uft.edu.br/component/option,com docman/...0/.../gid,922/>. Acesso em: 22/01/2015.

\section{ANEXO - QUESTIONÁRIO}

Prezado aluno da EAD - Curso de Ciências Biológicas - Consórcio Setentrional - UFMS

Por meio desta, solicitamos que você responda aos questionamentos a seguir, relacionados ao funcionamento do curso e a seu desempenho. Essas informações auxiliarão na elaboração de um trabalho que visa a avaliar o perfil do aluno neste curso. Não há necessidade de identificação pessoal, mas os demais dados são importantes. Sua opinião é extremamente importante. Obrigado.

As questões que você deixar em branco serão consideradas como negativas ou já respondidas por uma anterior.

1. Sexo: ( ) masculino ( ) feminino

2. Idade: ( ) entre 18 e 28 anos ( ) entre 29 e 39 anos

( ) entre 40 e 50 anos ( ) acima de 51 anos

3. Quando ingressou no curso, há quanto tempo tinha concluído o ensino médio (segundo grau)?

( ) até 5 anos ( ) de 6 a 10 anos

( ) de 11 a 20 anos ( ) mais de 20 anos

4. Já fez outro curso superior?

( ) não

( ) sim, mas não concluí. Especifique qual e por quanto temo:

( ) sim. Especifique qual e o ano da formatura:

5. Estado civil: ( ) solteiro ( ) casado/união estável

( ) separado/divorciado/viúvo

( ) separação durante o período em que já estava fazendo o curso 
6. Número de filhos: (marque números)

( ) nascidos durante o curso ( ) entre 2 e 10 anos

( ) entre 11 e 18 anos ( ) acima de 18 anos

7. Número de netos: (marque números)

( ) nascidos durante o curso ( ) entre 2 e 10 anos

( ) entre 11 e 18 anos ( ) acima de 18 anos

8. Em sua opinião, se você tivesse que avaliar o apoio que seus familiares the dão para que você estude, você diria que esse apoio é:

( ) total ( ) parcial

( ) foi variável até agora, havendo pessoas que apoiam e outras que não

( ) foi variável ao longo do tempo, havendo momentos de apoio e outros em Ihe faltou apoio

9. No caso de haver atritos em sua família em decorrência do seu estudo, isso ocorreu com: (pode marcar mais de uma)

( ) cônjuge/namorado ( ) filhos ( ) netos

( ) irmãos ( ) pais ( ) outros

10. Local onde reside:

( ) casa/apartamento na área urbana

( ) casa/chácara periferia da na área urbana

( ) área rural distante até $20 \mathrm{~km}$ do polo

( ) área rural distante entre 21 e $50 \mathrm{~km}$ do polo

( ) área rural distante mais de $100 \mathrm{~km}$ do polo

11. No caso de você morar na área rural, até chegar à cidade, o caminho:

( ) é todo pavimentado ( ) a maior parte pavimentado

( ) a maior parte de terra ( ) todo de terra

12. Na maioria das vezes, você se desloca para o polo:

( ) a pé ( ) de carro particular

( ) de motocicleta particular ( ) de carona

( ) de bicicleta ( ) a cavalo/charrete ( ) de ônibus

13. Quanto tempo você leva para se deslocar de sua casa até o polo?

( ) até meia hora ( ) de meia a uma hora

( ) de uma a duas horas ( ) de duas a três horas

( ) mais de três horas

14. Quanto ao trabalho doméstico em sua casa:

( ) sou eu quem faço

( ) tenho empregada nos dias úteis

( ) tenho diarista que vai uma vez por semana

( ) tenho diarista que vai duas ou três vezes na semana

( ) divido ou serviço doméstico com outra pessoa que mora comigo

( ) não tenho empregada, mas não sou eu quem faço o serviço doméstico ou pouco participo dele 
( ) não tenho empregada, mas quando preciso estudar tem uma pessoa que me ajuda

15. Você trabalha fora? ( ) sim ( ) não

16. No caso de trabalhar fora, qual sua profissão? (Se for professor, especifique o nível).

17. Ainda quanto ao seu trabalho: (pode marcar mais de uma resposta):

( ) Trabalho por conta própria e tenho horário flexível

( ) Sou funcionário e trabalho até 4 horas diárias.

( ) Sou funcionário e trabalho 6 horas diárias.

( ) Sou funcionário e trabalho 8 horas diárias.

( ) Trabalho também aos sábados.

( ) Além dos horários de trabalho, eu ainda costumo levar trabalho para casa.

( ) Tenho facilidade em faltar ao trabalho ou trocar horários quando preciso estudar.

18. Com que frequência você participa das atividades de apoio com o tutor presencial?

( ) sempre ou quase ( ) de vez em quando

( ) raramente ( ) nunca ou quase nunca

19. Quantas horas por semana você dedica ao estudo ou atividades do curso?

20. Está cursando o módulo atual (módulo 5)? ( ) sim ( ) não

21. Mesmo que você tenha abandonado o curso, responda aos questionamentos referentes aos módulos que cursou.

Módulo 1

( ) com facilidade

( ) com dificuldade ,mas não carreguei nenhuma pendência

( ) com dificuldade, carreguei pendências, mas já as resolvi

( ) com dificuldade e ainda tenho pendências não resolvidas

Módulo 2

( ) com facilidade

( ) com dificuldade, mas não carreguei nenhuma pendência

( ) com dificuldade, carreguei pendências, mas já as resolvi

( ) com dificuldade e ainda tenho pendência não resolvidas

Módulo 3

( ) com facilidade

( ) com dificuldade, mas não carreguei nenhuma pendência

Revista Educação Online, n. 19, jun-ago 2015, p. 166-201 
( ) com dificuldade, carreguei pendências, mas já as resolvi

( ) com dificuldade e ainda tenho pendência não resolvidas

\section{Módulo 4}

( ) com facilidade

( ) com dificuldade, mas não carreguei nenhuma pendência

( ) com dificuldade, carreguei pendências, mas já as resolvi

( ) com dificuldade e ainda tenho pendência não resolvidas

22. Todos temos dificuldades. Alguns mais, outros menos. Nas frases a seguir, assinales aquelas que você acha que estão mais relacionadas aos seus problemas, em ordem crescente, ou seja, o 1 deve ser o que você acha ser 0 principal fator que o/a leva a ter dificuldades, tendo como consequência as possíveis pendências e até, se for o seu caso, o fato de você ter abandonado o curso. $\mathrm{O}$ que não estiver relacionado aos seus problemas, deixe em branco:

( ) não consigo aprender com uma estrutura de curso a distância, no qual existem poucas aulas presenciais.

( ) participo pouco de estudos em grupo.

( ) participo pouco das atividades com o tutor local.

( ) falto muito as poucas atividades presenciais que ocorrem.

( ) tenho dificuldade de entendimento, porque não me lembro do que estudei no ensino médio.

( ) tenho dificuldades em língua portuguesa, o que me leva a dificuldades em entender a linguagem de livros de modo geral.

( ) tenho dificuldades em língua portuguesa, o que me leva a dificuldades em escreve as minhas respostas em atividade e provas.

( ) tenho dificuldade de entender a linguagem especificamente do livro utilizado - quando consulto outros livros a nível de graduação, não tenho esse problema.

( ) estudo muito, mas não consigo gravar por muito tempo as informações e esqueço.

( ) fico nervoso na hora das provas e não consigo fazer - tenho os famosos "brancos".

( ) me envolvo com atividades de trabalho e não consigo estudar.

( ) me envolvo com atividades domésticas ou familiares e não consigo estudar.

( ) tenho dificuldade de concentração: começo a estudar e me distraio com algum fator externo.

( ) não tenho o apoio que preciso de familiares.

( ) nos momentos de folga, priorizo atividades sociais, como festas e passeios, e acabo não estudando.

( ) por timidez ou inibição, não entro em contato com o tutor local, levando minhas dúvidas. 